\title{
Quaternary marine terraces on Sal Island (Cape Verde archipelago)
}

\author{
C. Zazo ${ }^{\mathrm{a}, *}$, J.L. Goy ${ }^{\mathrm{b}}$, C.J. Dabrio ${ }^{\mathrm{c}}$, V. Soler ${ }^{\mathrm{d}}$, Cl. Hillaire-Marcel ${ }^{\mathrm{e}}$, B. Ghaleb ${ }^{\mathrm{e}}$, \\ J.A. González-Delgado ${ }^{\mathrm{b}}$, T. Bardajif ${ }^{\mathrm{f}}, \mathrm{A}$. Cabero ${ }^{\mathrm{a}}$ \\ ${ }^{a}$ Departamento de Geología, Museo Nacional de Ciencias Naturales, CSIC, José Gutiérrez Abascal, 2. 28006, Madrid, Spain \\ ${ }^{\mathrm{b}}$ Departamento de Geología, Facultad de Ciencias, Universidad de Salamanca. 37008, Salamanca, Spain \\ ${ }^{\mathrm{c}}$ Departamento de Estratigrafia, Facultad de Ciencias Geológicas and Instituto de Geología Económica CSIC. Universidad Complutense, \\ 28040, Madrid, Spain \\ ${ }^{\mathrm{d}}$ Estación Volcanológica de Canarias, CSIC, Avda. Astrofísico Fco. Sánchez 3, 38206 La Laguna-Tenerife, Spain \\ ${ }^{\mathrm{e}}$ GEOTOP-UQAM, Montréal, Canada H3C $3 P 8$ \\ ${ }^{\mathrm{f}}$ Departamento de Geología, Facultad de Ciencias, Universidad de Alcalá, 28871-Alcalá de Henares, Spain
}

Received 11 July 2006; accepted 18 December 2006

\begin{abstract}
The Quaternary sedimentary record of Sal Island includes marine and related aeolian and alluvial fan deposits. The substratum of the island is volcanic, with ages between 25 and $0.6 \mathrm{Ma}$. Quaternary marine units generally occur as raised marine terraces forming a broad staircase between elevations of 55-60 $\mathrm{m}$ and present sea level. Terraces include a basal conglomerate overlaid by calcarenite; both host corals, algae and molluscs.

A chronostratigraphic framework for the Middle Pleistocene to Holocene units has been generated based on a geomorphologic map of the Quaternary landforms and associated deposits and morphosedimentary analysis, with support of laboratory dating: U-series by TIMS in corals, ${ }^{14} \mathrm{C}$ analyses, palaeomagnetic measurements, and $\mathrm{K} / \mathrm{Ar}$ ages from other literature. U-series dating of corals from marine terraces provides benchmarks for the Last Interglacial (Oxygen Isotope Substage 5e) and Holocene deposits. The present elevation of the marine terraces and their staircase arrangement suggest a change in vertical movement trend around $330 \mathrm{ka}$ from an uplift to either subsidence or stabilization.
\end{abstract}

\section{Introduction}

The Cape Verde archipelago is an unusually wellpreserved area for studying recent vertical crustal movements related to volcanic activity and/or tectonics. Additionally it allows investigation of behaviour, intensity and trajectories of the oceanic currents forming the socalled "Subtropical North Atlantic Gyre" in the recent past as well as in the present.

Sal Island, one of the easternmost islands of the archipelago, is extremely arid and offers easy access to the well-preserved Quaternary deposits, particularly to the raised marine terraces. These landforms are very similar in number and elevation to those studied by us in the eastern

\footnotetext{
*Corresponding author. Tel.: + 34914111328x1189; fax: +34915644740 .

E-mail address: monzc65@mncn.csic.es (C. Zazo).
}

Canary Islands on Fuerteventura and Lanzarote Islands (Zazo et al., 2002).

Despite the excellent exposures on Sal Island, Quaternary deposits have received very little attention, except for papers by Lecointre $(1962,1963,1965)$ which cited three marine terraces containing the warm-water gastropod Strombus bubonius at elevations of 55-13, 7-8 m, and around mean sea level. A comparison between the coasts of Morocco and the Mediterranean Sea led Lecointre to assign these terraces to the Anfatian (Tyrrhenian $I=$ Eutyrrhenian), Ouljian (Tyrrhenian II = Neotyrrhenian) and Flandrian (Mellahian) respectively. This chronology has been followed in later studies (Serralheiro, 1967; Silva et al., 1990, etc.) devoted to volcanic rock and also to those having to do with to the faunal content of the topographically-low (between 0 and $5 \mathrm{~m}$ ) deposits (García-Talavera and Bacallado, 1981; García-Talavera, 1999). 
This study provides the first geomorphologic map of the Quaternary landforms and associated deposits including the sequence of raised marine terraces and the associated terrestrial and transitional deposits, the main sedimentological and morphological features and (still under study) the faunal content. A chronostratigraphic framework has been generated by means of palaeomagnetic analyses, $\mathrm{K}$-Ar dating (Torres et al., 2002a), U-series measurements (mainly on corals) and radiocarbon dating. This paper focuses on the raised Quaternary marine terraces in order to investigate sea level changes and possible vertical crustal movements. It also supplies data for an improved knowledge of the source areas of the "Senegalese fauna" that is thought to have migrated from tropical Atlantic regions into the Mediterranean Sea, where it spread extensively during the Last Interglacial (OIS 5).

\section{Physiographical and geological setting}

The Cape Verde archipelago consists of ten main islands of volcanic origin located in the central Atlantic Ocean (Fig. 1A), $450 \mathrm{~km}$ off the African mainland (Senegal) and $2500 \mathrm{~km}$ east from the Mid-Atlantic ridge. Together with the Azores, Salvagens, Canary and Madeira archipelagos, they form the Macaronesian bio-geographic region, a term coined in the 19th century by Barker-Webb and Berthelot (1836-1840) to include islands with volcanic substrata and a marked endemic species. The islands are in the path of the Northern Hemisphere trade-winds and are separated in windward and leeward islands (Fig. 1B). Besides the prevailing trade winds felt all along the year, the warm eastern harmattan blows between December and April.

Sal Island (one of the Windward Islands) is $216 \mathrm{~km}^{2}$ in surface area. It is also topographically the flattest of the archipelago with only a few, isolated mountains. The highest of these is The Monte Grande (elevation: $406 \mathrm{~m}$ ) at the northeastern part of the island (Fig. 2). The climate in the island is tropical-dry. During the dry season (November-June) mean temperatures are $28^{\circ} \mathrm{C}$, but in the rainy season (August-October) mean temperatures fall to around $19{ }^{\circ} \mathrm{C}$. Rain is very scarce (mean annual rainfall $\sim 102 \mathrm{~mm}$ ), and the island lacks permanent surficial water courses even during the rainy season. In fact, the island is the most arid of the whole archipelago. The mean annual average tidal range in these islands is $1 \mathrm{~m}$.

The available geochronologic data (Torres et al., 2002a) suggest that the earlier stages of volcanism in the Cape Verde archipelago are younger in a southwestern direction, a pattern congruent with the apparent oceanic plate motion relative to the Cape Verde hot-spot. The few published data suggest ages ranging between $21.1 \pm 6.3$ and $4.3 \pm 0.2 \mathrm{Ma}$ for the Old Eruptive Complex, and between $12 \pm 2$ and $2.4 \pm 0.2 \mathrm{Ma}$ for the Main Eruptive Formation described in the islands of Maio, Santiago and Brava (Torres et al., 2002a). Recent $\mathrm{K} / \mathrm{Ar}$ analyses of seven samples collected on Sal Island (Torres et al., 2002a), coupled with detail geological mapping (Fig. 2), established a chronostratigraphic sequence for the volcanic activity in the island with ages ranging from $25.6 \mathrm{Ma}$ to about $0.6 \mathrm{Ma}$.

The oldest sedimentary units described in Sal Island are marine calcarenites found in Ribeira de Fragata-Serra Negra (Silva et al., 1993; Torres et al., 2002a, b), that have been tentatively assigned to an Uppermost MiocenePliocene age. A large part of the island is occupied by broad platforms topped by fossiliferous marine limestones and calcarenites, which are known locally as lajedos (Fig. 2). They occur at elevations between 2 and $100 \mathrm{~m}$ a.s.1.
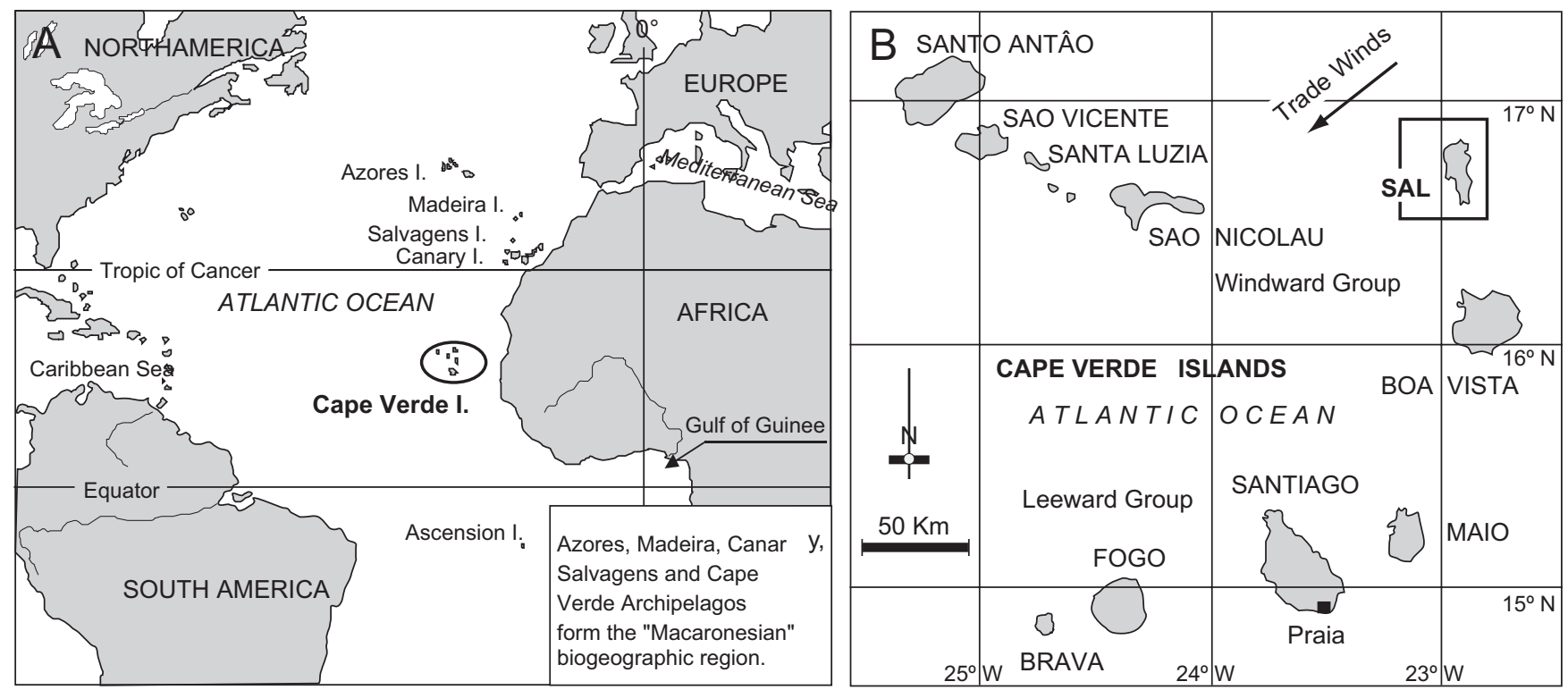

Fig. 1. (A) Location map of Cape Verde Islands in eastern North Atlantic Ocean. (B) Groups of islands according to the prevailing direction of trade winds. 


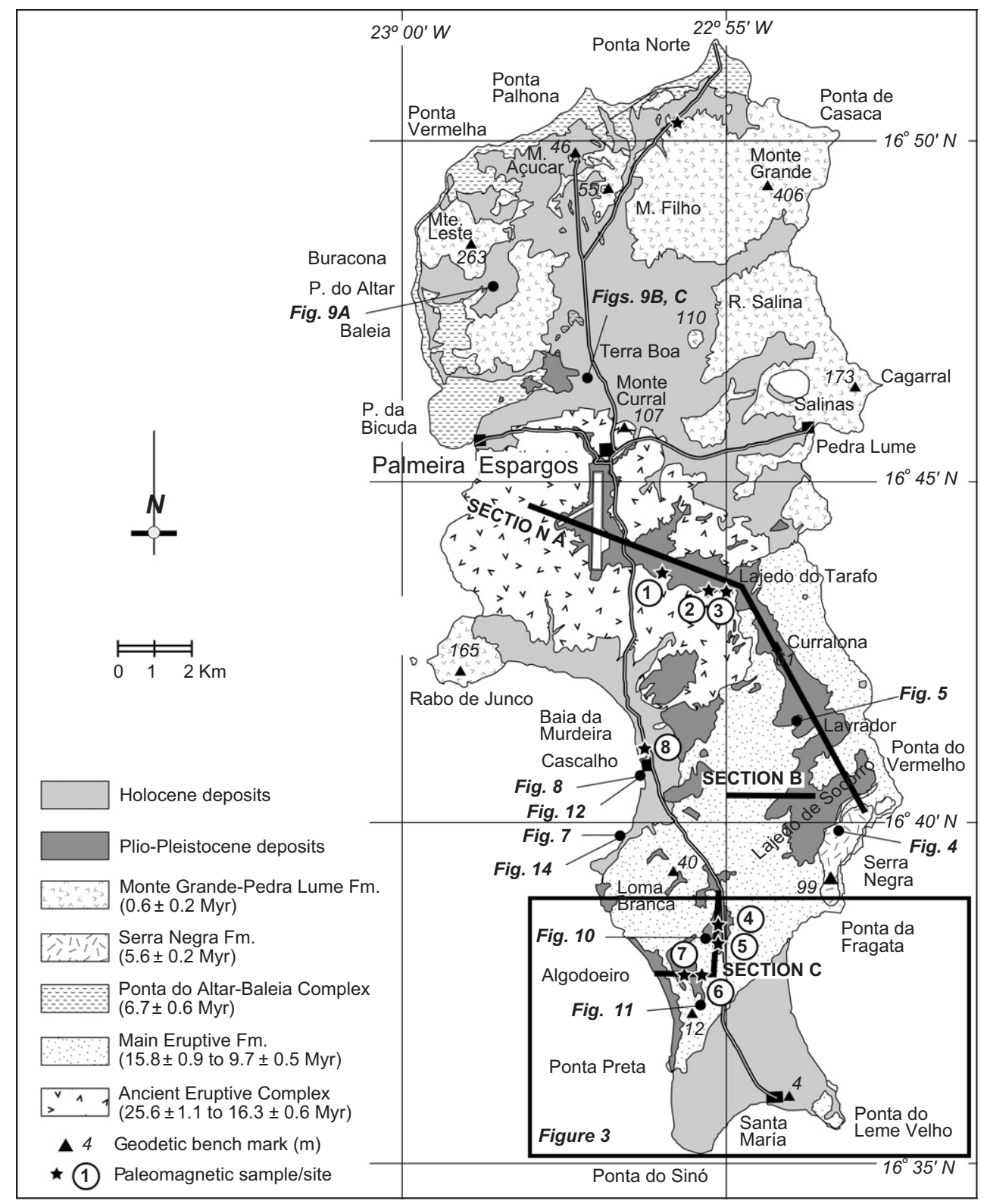

Fig. 2. Geologic map of Sal Island (modified after Torres et al., 2002a) with sections depicted in Fig. 6 and location of photographs.

(above sea level) and are marine terraces of Pleistocene age (Torres et al., 2002b).

\section{Materials and methods}

\subsection{Air photo-mapping and field investigations}

The first step was to construct a detailed geomorphologic map of the Quaternary landforms and associated marine and terrestrial deposits, and the volcanic rocks related with them, based on aerial photographs scaled 1:15.000 (year 1991) and to field check the features represented (Fig. 3). Data were transferred to the topographic 1:25.000 (sheets 27-Preguiça, 28-Espargos, and 29-Santa Maria) and geologic (sheets I and II) maps, and checked in the field.
Torres et al. (2002a, b) described and mapped in detail the volcanic rocks of Sal Island. In contrast, Quaternary sedimentary rocks received less attention, as only Pleistocene and Holocene deposits were differentiated (Fig. 2) and few lithologic details offered.

Sampling of morphosedimentary units was preceded by facies analysis of sedimentary units aimed to separate shallow marine, beach, lagoon and terrestrial (alluvial fan and sand dunes) coastal facies. This is essential as a means of fixing the present topographic elevation of a given marine unit with respect to the present sea level, used as datum, and to reveal any possible eustatic oscillation of sea level.

In this paper the elevations of marine terraces refer to the mean high tide level (datum $=0 \mathrm{~m}$ ), and the altitudes 
have been measured in the inner part of the marine edge (the shoreline angle) using topographic maps, altimeter and rod. We consider that the mapped marine terrace deposits represent sea-level highstands during either interglacial or interstadial episodes (Oxygen Isotope Stage-OIS or Oxygen Isotopic Substage-OISS). In the case of the Last Interglacial (OISS 5e), two different events have been mapped. Marine terraces have been numbered following the stratigraphic order from T.1 (the oldest) through T.16 (the youngest, see Fig. 3 legend). Most Holocene deposits are beach barrier-lagoon systems and aeolian sands.

\subsection{Paleontology}

Fossils have been collected from the marine terraces and a palaeontologic study is underway. The study pays particular attention to Strombus bubonius and the accompanying fauna-usually referred to as the "Senegalese warm fauna" - which colonized the coasts of the western Mediterranean (Hearty et al., 1986; Cuerda, 1989; Goy et al., 1993; Hillaire-Marcel et al., 1996; Zazo et al., 2003), Canary Islands (Meco et al., 1997; Zazo et al., 2002, 2004) and other Macaronesian archipelagos (García-Talavera, 1987, 1999; Avila, 2000; Callapez and Ferreira Soares,

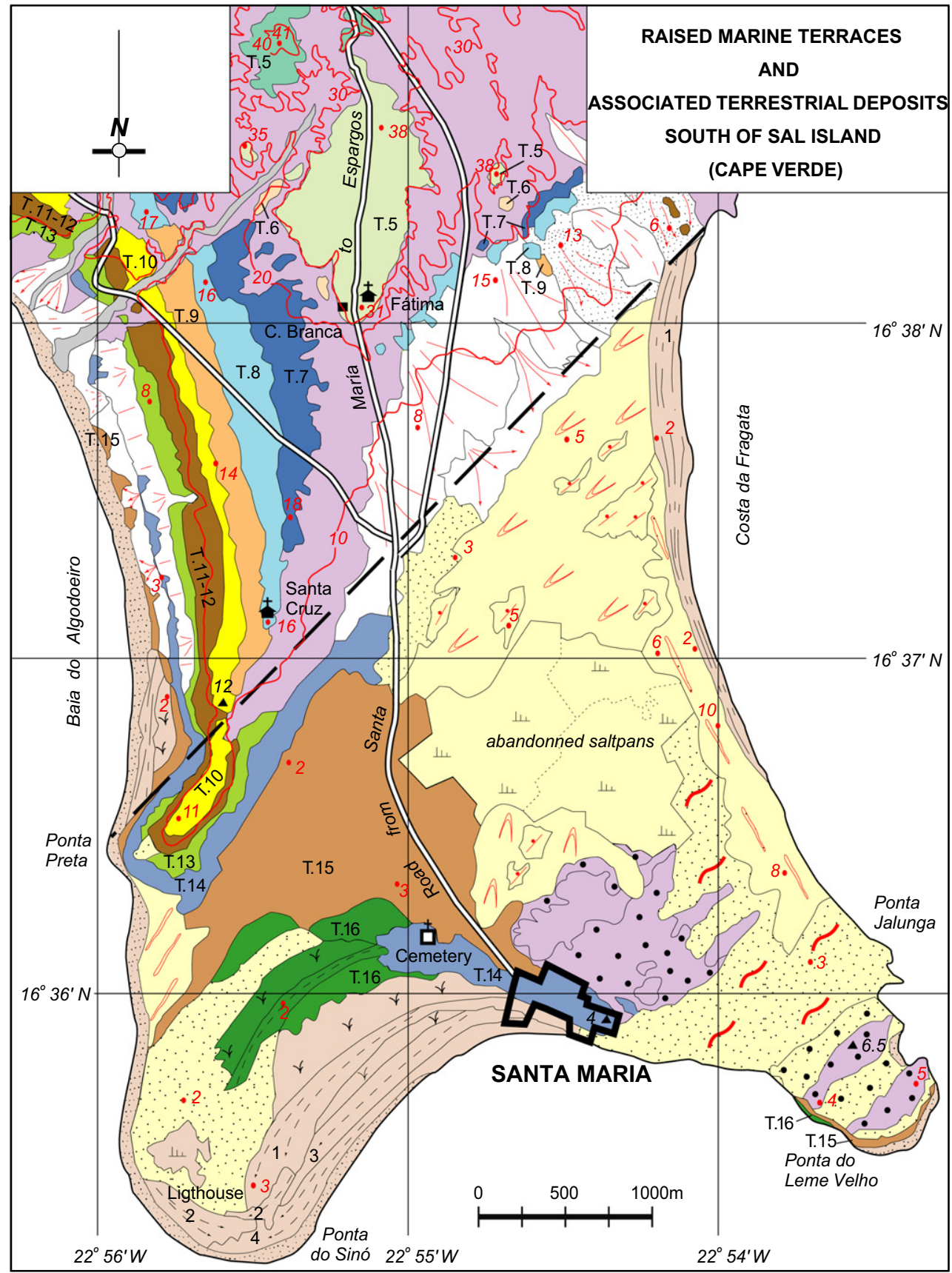

Fig. 3. Geomorphologic map and legend of Quaternary landforms and associated deposits in southern Sal Island (Cape Verde). 


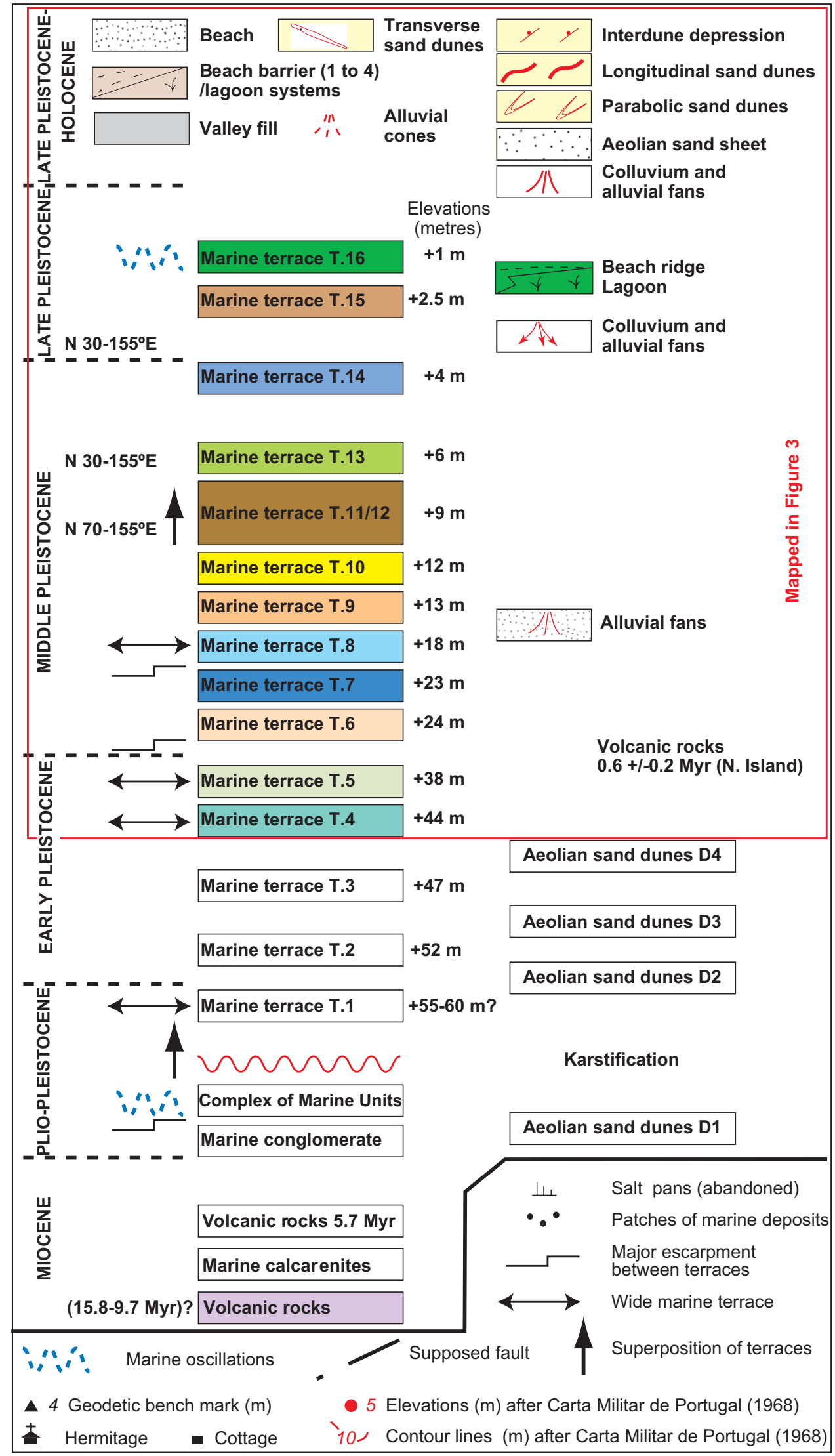

Fig. 3. (Continued) 
2000; Avila et al., 2002) during some of the Pleistocene interglacials. Some palaeoecological conditions of this fauna have been deduced by comparing the morphosedimentary record and faunal content of the two most recent marine terraces with the results by Morri and Bianchi (1995) and Morri et al. (2000) on living shallow epibenthic communities.

Fossil corals found in the marine terrace deposits received special attention because they are the marine organisms most suitable for U-series dating. A major issue is to differentiate hydrozoan from true scleractinian corals.

\subsection{Petrology}

Thin sections of lithified sediments in the oldest marine terraces were used to study microfacies and cements, wich may yield a better interpretation of sedimentary facies. Thin sections are particularly helpful in the cemented carbonate deposits, where sedimentary discontinuities are difficult to trace in the field, and only apparently-massive morphosedimentary units are observed. The final aim of these studies is to reconstruct sea-level oscillations.

\subsection{Paleomagnetic analysis}

42 cores for paleomagnetic analysis were drilled in situ and oriented by a solar compass in the sedimentary Complex of Marine Units (C.M.U.), some of the cemented marine terrace deposits, and the volcanic rocks of the Monte Grande Formation. From these cores we extracted 71 samples. The natural magnetic remanization (NRM) measurements were performed in an Agico JR4 magnetometer, using stepped thermal demagnetization to $600^{\circ} \mathrm{C}$ in a Sconstedt TDS-1 oven.

The thermal treatment worked well with the majority of the samples, with the exception of those from Monte Grande, that seem to be affected by electrical discharges, presenting highly erratic initial NMR directions that did not improve with thermal treatment. Alternating field treatment above $30 \mathrm{mT}$ allowed this superimposed viscous component to be removed and the positive polarity of this formation to be established.

\section{5. ${ }^{14} \mathrm{C}$ analysis}

A few AMS radiocarbon analyses were carried out on shells extracted from the lowest marine terrace, and on recent aeolian deposits at Geochron Laboratories (Cambridge, Mass, USA).

\subsection{U-series measurements}

Samples were mechanically cleaned and crushed in an agate mortar. Aliquots were put aside for aragonite-calcite and stable isotope measurements. Analytical procedures for $\mathrm{U}$ and Th separation followed Edwards et al. (1987), with a modified two stage extraction with $6 \mathrm{~N} \mathrm{HCl}$ and $7 \mathrm{~N}$
$\mathrm{HNO}_{3}$ to increase the yield of $\mathrm{U}$ (see Hillaire-Marcel et al., 1996 for more details). Measurements were made on a VGSector thermal ionization mass spectrometer equipped with an electrostatic filter and an ion-counting device. The overall analytical reproducibility, as estimated from replicate measurement of standards, is usually better than $\pm 0.5 \%$ ( $\pm 2 \sigma$ error) for $U$ and $T h$ concentrations as well as for ${ }^{234} \mathrm{U} /{ }^{238} \mathrm{U}$ and ${ }^{230} \mathrm{Th} /{ }^{234} \mathrm{U}$ ratios (Table 1).

\subsection{X-ray determination of aragonite-Calcite ratios}

Determination of calcite/aragonite ratios was made using X-ray diffraction measurements (Davies and Hooper, 1963), with a Siemens D 5000 instrument (CoK $\alpha$ radiation). We used the aragonite 111 and calcite 104 reflection peaks and expressed aragonite contents in percent of total carbonate from $(111 / 111+104)$ ratios. Measurements of standard aragonite-calcite mixtures for calibration purposes show that either peak heights or peak areas can be used. Replicate measurements of laboratory standards show a reproducibility of about $5 \%( \pm 1 \sigma)$.

\section{Results and discussion}

\subsection{The geomorphologic map of the Quaternary Landforms and associated deposits}

We mapped the entire Sal Island. In the north, some of the marine terraces rest directly on top of the youngest volcanic rocks of the island, which is most interesting from a geochronologic point of view. In this paper we only present a map of the southern part of the island, where the most complete succession of marine and terrestrial morphosedimentary units is exposed (Fig. 3).

We have distinguished sixteen marine terraces (T.1 trough T.16 in stratigraphic order) that lay at elevations between $55 \mathrm{~m}$ a.s.l. and modern sea level $(0 \mathrm{~m})$. Some of them are of quite broad and their deposits rest upon erosion surfaces cut by waves onto volcanic rocks, an observation that suggests that they probably represent long periods of stable sea level. These features have been indicated in the map and legend (Fig. 3), along with the main paleo-cliffs separating consecutive terraces. Elevations (in metres) refer to the altitude a.s.l. of the shoreline angle. Some terraces, such as T.11 and T.12, occur vertically stacked in the mapped sections.. This is also indicated in the legend of the map.

Holocene marine deposits lack the morphological expression of emergent terraces, but still have the sedimentary signature of beaches or beach barrier-lagoon, and aeolian systems.

\subsection{Marine deposits}

\subsubsection{Pre-Quaternary deposits}

The oldest sedimentary unit described in Sal Island is composed of marine calcarenites (Silva et al., 1990, 1993; 
Table 1

U-series measurements, $\delta^{13} \mathrm{C}$ and $\delta^{18} \mathrm{O}$ in samples from Sal Island

\begin{tabular}{|c|c|c|c|c|c|c|c|c|c|c|c|c|c|}
\hline Sample \# & Sample ID & Arag. $\%$ & ${ }^{238} \mathrm{U}(\mathrm{ppm})$ & ${ }^{232} \mathrm{Th}(\mathrm{ppb})$ & ${ }^{234} \mathrm{U} /{ }^{238} \mathrm{U}^{*}$ & ${ }^{230} \mathrm{Th} /{ }^{234} \mathrm{U}^{*}$ & ${ }^{230} \mathrm{Th} /{ }^{232} \mathrm{Th}^{*}$ & \multicolumn{2}{|c|}{ Calc.age (ka) } & $\delta^{234} \mathrm{U}_{0} \%$ & Group & $\delta^{13} \mathrm{C}$ & $\delta^{18} \mathrm{O}$ \\
\hline \multicolumn{14}{|l|}{ Coral samples } \\
\hline S03-64 & Favia fragum & 98.7 & $2.505 \pm 0.015$ & $2.278 \pm 0.016$ & $1.1525 \pm 0.0086$ & $0.0016 \pm 0.0001$ & $6.34 \pm 0.46$ & 0.18 & $\pm 0.013^{* *}$ & $153 \pm 9^{* *}$ & A & 1.34 & 0.26 \\
\hline S03-57 & Unidentified coral & n.d. & $2.4739 \pm 0.0151$ & $129.64 \pm 1.4092$ & $1.2020 \pm 0.0073$ & $0.6627 \pm 0.1240$ & $43.29 \pm 0.93$ & 114.8 & $+4 /-3.8$ & $280 \pm 10$ & B & - & - \\
\hline S03-65 & Favia fragum & 97.8 & $2.909 \pm 0.018$ & $0.4029 \pm 0.0048$ & $1.1293 \pm 0.0100$ & $0.6891 \pm 0.0100$ & $17172 \pm 302$ & 122.9 & $+3.6 /-3.4$ & $183 \pm 14$ & B & 1.14 & -2.40 \\
\hline S03-68-1 & Siderastrea radians & n.d. & $2.703 \pm 0.015$ & $1.647 \pm 0.011$ & $1.0976 \pm 0.0062$ & $0.6586 \pm 0.0047$ & $3624 \pm 35$ & 114.2 & $+1.6 /-1.5$ & $135 \pm 9$ & B & -0.77 & -2.20 \\
\hline S03-68-2-e & S. radians (top) & 89.4 & $2.4197 \pm 0.0013$ & $36.044 \pm 0.028$ & $1.1220 \pm 0.0094$ & $0.6972 \pm 0.0088$ & $160.5 \pm 2.1$ & 125.7 & $+3.2 /-3.1$ & $174 \pm 13$ & B & -0.07 & -2.33 \\
\hline S03-68-2-d & S. radians (interm.) & 98.1 & $2.7304 \pm 0.0018$ & $3.050 \pm 0.029$ & $1.1214 \pm 0.0068$ & $0.7034 \pm 0.0074$ & $2158 \pm 31$ & 127.8 & \pm 2.7 & $174 \pm 10$ & B & 0.08 & -2.24 \\
\hline S03-68-2-c & S. radians (middle) & 98.25 & $2.6648 \pm 0.0119$ & $0.402 \pm 0.003$ & $1.1180 \pm 0.0067$ & $0.6971 \pm 0.0071$ & $15798 \pm 190$ & 125.8 & $+2.6 /-2.5$ & $169 \pm 10$ & B & 0.24 & -2.19 \\
\hline S03-68-2-b & S. radians (interm.) & 100 & $2.7629 \pm 0.0017$ & $2.762 \pm 0.034$ & $1.1150 \pm 0.0067$ & $0.7051 \pm 0.0100$ & $2404 \pm 45$ & 128.5 & $+3.7 /-3.5$ & $166 \pm 10$ & B & 0.20 & -1.74 \\
\hline S03-68-2-a & S. radians (bottom) & 98.3 & $2.703 \pm 0.0015$ & $7.633 \pm 0.006$ & $1.1030 \pm 0.0011$ & $0.7058 \pm 0.0104$ & $843 \pm 12$ & 129.2 & $+4.0 /-3.8$ & $149 \pm 2$ & B & 0.01 & -2.01 \\
\hline S03-69 & Siderastrea radians & 80.4 & $2.767 \pm 0.016$ & $40.72 \pm 0.36$ & $1.1008 \pm 0.0088$ & $0.6453 \pm 0.0080$ & $147.5 \pm 2.1$ & 110.2 & \pm 2.5 & $138 \pm 12$ & B & 1.37 & -2.88 \\
\hline S02-8 & Unidentified coral & n.d. & $1.4473 \pm 0.0066$ & $51.83 \pm 0.36$ & $1.1253 \pm 0.0086$ & $1.0348 \pm 0.0108$ & $99.4 \pm 1.1$ & $>>$ & & - & & - & - \\
\hline S02-9 & Favia fragum & 56.8 & $2.713 \pm 0.014$ & $13.277 \pm 0.093$ & $1.0997 \pm 0.0099$ & $0.971 \pm 0.0112$ & $666.8 \pm 7.5$ & 312 & $+26 /-21$ & $241 \pm 22$ & $\mathrm{C}$ & 2.03 & -1.15 \\
\hline S03-54 & Siderastrea radians & n.d. & $2.752 \pm 0.026$ & $2.364 \pm 0.027$ & $1.0650 \pm 0.0094$ & $0.9671 \pm 0.0128$ & $3663 \pm 65$ & 322 & $+35 /-26$ & $162 \pm 23$ & $\mathrm{C}$ & -2.90 & -7.19 \\
\hline S03-55 & Siderastrea radians & 98.8 & $2.879 \pm 0.019$ & $1.6104 \pm 0.0037$ & $1.0644 \pm 0.0071$ & $0.9770 \pm 0.0209$ & $5681 \pm 177$ & 343 & $+73 /-43$ & $170 \pm 19$ & $\mathrm{C}$ & 1.82 & -2.49 \\
\hline S03-73 & Favia fragum & 94.8 & $2.467 \pm 0.014$ & $17.92 \pm 0.13$ & $1.0716 \pm 0.0077$ & $0.9732 \pm 0.0083$ & $438.7 \pm 4.5$ & 330 & $+24 /-19$ & $182 \pm 20$ & $\mathrm{C}$ & 1.49 & -1.89 \\
\hline S03-70 & Siderastrea radians & 95.4 & $3.272 \pm 0.020$ & $4.678 \pm 0.049$ & $1.0355 \pm 0.0071$ & $1.0005 \pm 0.0104$ & $2214 \pm 31$ & $>>$ & & - & $\mathrm{D}$ & -1.79 & -2.99 \\
\hline S03-77 & Siderastrea radians & n.d. & $2.348 \pm 0.019$ & $0.0658 \pm 0.0011$ & $1.0156 \pm 0.0058$ & $1.0192 \pm 0.0113$ & $>10^{5} \pm 2 * 10^{3}$ & $>>$ & & - & $\mathrm{D}$ & 2.89 & -2.65 \\
\hline S03-79 & Favia fragum & 0 & $2.6104 \pm 0.0014$ & $10.400 \pm 0.089$ & $1.0021 \pm 0.0049$ & $1.0049 \pm 0.0084$ & $772.5 \pm 9.4$ & $>>$ & & - & $\mathrm{D}$ & - & - \\
\hline \multicolumn{14}{|c|}{ Other measurements } \\
\hline S03-58 & Millepora $\mathrm{sp}$. & 98.8 & $0.8450 \pm 0.0040$ & $153.7 \pm 1.2$ & $1.1516 \pm 0.0060$ & $<<$ & $<<$ & Modern & & $115 \pm 6$ & A & 0.74 & 0.10 \\
\hline S03-51 & Millepora $\mathrm{sp}$. & 96.6 & $0.6709 \pm 0.0044$ & $0.791 \pm 0.009$ & $1.1699 \pm 0.0075$ & $0.0025 \pm 0.0017$ & $7.5 \pm 5.1$ & 0.3 & $\pm 0.2^{* *}$ & $170 \pm 8 * *$ & A & 1.20 & -0.07 \\
\hline S03-52 & Dendropoma sp. & 98.1 & $0.7727 \pm 0.0043$ & $5.989 \pm 0.052$ & $1.1623 \pm 0.0100$ & $0.0159 \pm 0.0013$ & $7.27 \pm 0.58$ & 1.7 & $\pm 0.1^{* *}$ & $163 \pm 10^{* *}$ & A & 0.96 & -0.58 \\
\hline S03-74 & Millepora sp. & 80.8 & $0.8379 \pm 0.0045$ & $104.2 \pm 1.18$ & $1.1627 \pm 0.0100$ & $0.6239 \pm 0.0124$ & $17.82 \pm 0.39$ & 103.0 & $+5.4 /-4.6^{* *}$ & $218 \pm 13^{* *}$ & B & 1.37 & 0.73 \\
\hline S03-61 & Millepora sp. & 78.9 & $0.5720 \pm 0.0030$ & $5.826 \pm 0.049$ & $1.1127 \pm 0.0100$ & $0.6990 \pm 0.0141$ & $233.5 \pm 4.8$ & 126.6 & $+5.1 /-4.9$ & $161 \pm 14$ & B & 1.29 & -2.11 \\
\hline S03-62 & Unid. shell fragment & n.d. & $0.1605 \pm 0.0014$ & $0.814 \pm 0.013$ & $1.2020 \pm 0.0103$ & $0.7314 \pm 0.0225$ & $529 \pm 18$ & 135.0 & $+8.5 /-7.9$ & $296 \pm 15$ & B & - & - \\
\hline S03-74 & Glycymeris sp. & n.d. & $0.1766 \pm 0.0009$ & $11.77 \pm 0.11$ & $1.1221 \pm 0.0089$ & $0.5665 \pm 0.0088$ & $29.14 \pm 0.50$ & 89.1 & $+2.3 /-2.2^{* *}$ & $218 \pm 13^{* *}$ & B & - & - \\
\hline S03-57 & Rodolite & n.d. & $0.6370 \pm 0.0060$ & $195.3 \pm 4.0$ & $1.1810 \pm 0.0180$ & $0.4630 \pm 0.0120$ & $5.45 \pm 0.17$ & 66.4 & $\pm 2.5^{* *}$ & $280 \pm 10^{* *}$ & $?$ & - & - \\
\hline $\mathrm{SO} 3-2$ & Dendropoma sp. & n.d. & $0.2337 \pm 0.0012$ & $51.116 \pm 0.010$ & $1.1554 \pm 0.0098$ & $0.6671 \pm 0.0115$ & $10.76 \pm 0.19$ & 115.4 & $+3.7 /-3.6$ & $216 \pm 14$ & B & - & - \\
\hline S03-66 & Millepora sp. & 90.9 & $1.1507 \pm 0.0058$ & $20.00 \pm 0.15$ & $1.1557 \pm 0.0077$ & $0.9997 \pm 0.0104$ & $193.5 \pm 2.3$ & 340 & $+28 /-23$ & $408 \pm 20$ & $\mathrm{C}$ & 1.35 & -0.53 \\
\hline
\end{tabular}

*Activity ratios.

**Ages and initial composition requiring correction due to high detrital content; A: recent (or late Holocene); B: assigned to OISS 5e; C and D older sets of samples (see Fig. 14). 
Torres et al., 2002a, b) belonging to the Fragata Formation that occur sandwiched between the volcanic Main Eruptive and Serra Negra Formations (Fig. 4). Silva et al. (1993) suggested an Uppermost Miocene, probably Pliocene, age for the calcarenites (Fig. 3). In the same section (Fig. 4) the volcanic rocks of the Serra Negra Formation are covered by an up-to $8 \mathrm{~m}$-thick marine conglomerate which Silva et al. (1993) assigned to the Quaternary. After considering the position of these deposits in the stratigraphic section, we hypothesize that they are somewhat older (Plio-Pleistocene, Figs. 3 and 4). The deposits reach a maximum elevation of ca $70 \mathrm{~m}$ and are covered by the oldest aeolianites recognized on the Island (D1), which host terrestrial gastropods (Helix sp.).

\subsubsection{The complex of marine units}

The extensive surface that forms the Tarafo and Socorro lajedos (Fig. 2) cuts the sequence of marine and aeolian dune deposits described above. The surface is incised by creeks, two of which are the Ribeiras de Beirona and Madama do Baixo. The walls of these creeks expose several

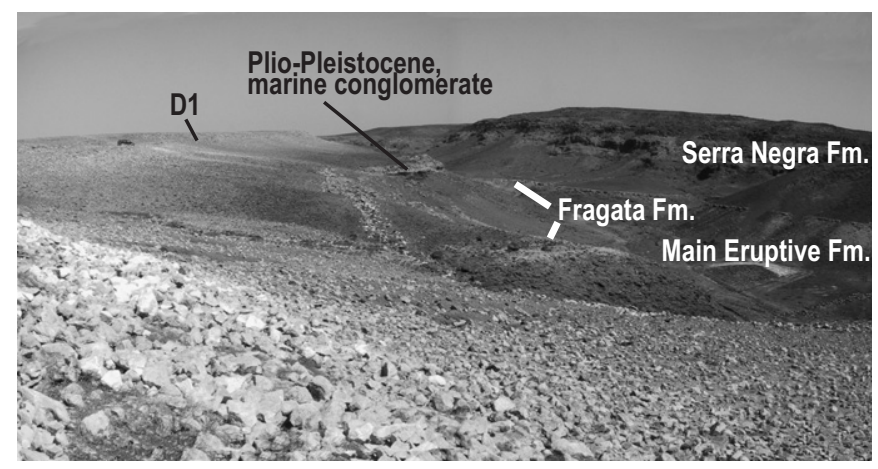

Fig. 4. Panorama of Ribeira (ravine) de Fragata and Serra Negra, with the oldest sedimentary marine units recognized in Sal Island. vertically-stacked marine units, older than the succession of marine terraces but younger than the pre-Quaternary deposits described above. We refer informally to these marine deposits as the Complex of Marine Units (CMU, Fig. 5) because they are actually a vertical superposition of units separated by erosional, and in some cases karstified, surfaces. The CMU rests unconformably on an erosion surface cut onto the volcanic rocks, hence the laterally variable thickness between 4 and $8 \mathrm{~m}$.

The lowermost sub-unit consists of white, poorly sorted packstone to grainstone, with angular pebbles of volcanic rocks. The locally abundant fossils include coralline algae and molluscs, but most are poorly preserved. Burrowing is low to medium, both parallel and normal to bedding. Despite a general nodular appearance, parallel-lamination and (local) wave-ripple cross-lamination are preserved. In some places, there is a prograding pattern to the SW ( 1 in Fig. 5), probably a function of the underlying erosion surface. We interpret these sediments as an open-shelf, marine deposit.

The lowermost sub-unit is overlain by an erosion surface, which in turn is covered by a light-brown fossiliferous conglomerate including clasts of the underlying white limestone. The thickness of this sub-unit exceeds one meter (west of the outcrop), but it pinches out to the east, while changing to cross-bedded calcarenite. This basal sub-unit is covered by yellowish, fossiliferous (mainly molluscs and coralline algae) calcarenites arranged in three large-scale, low-angle, cross-bedded sub-units. The dip of cross bedding in the two lower subunits is $\mathrm{N} 70{ }^{\circ} \mathrm{E}(2 \mathrm{a}$ and $2 \mathrm{~b}$ in Fig. 5), whereas in the third, uppermost subunit (not visible in Fig. 5) it is N250 ${ }^{\circ} \mathrm{E}$. A peculiar feature of the two first subunits is the occurrence, at the toe of the crossbedded units, of smaller-scale planar cross bedding, very much like that found in the plunge-step of the lower foreshore. Therefore, at first sight, these units could be mistaken as prograding beaches, but we interpret these

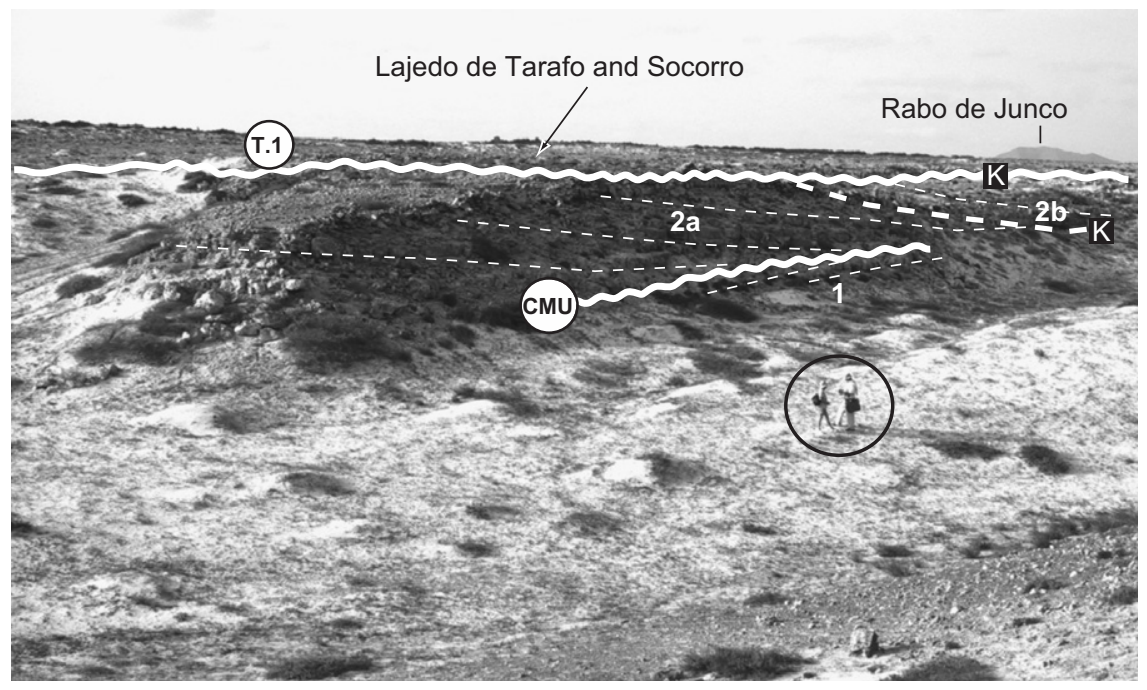

Fig. 5. Panorama of the Complex of Marine Units (CMU) and the overlying T.1 in the western wall of Ribeira de Beirona, near Lavrador summit (65 m), between Lajedos do Socorro and do Tarafo. Explanation in text. 
subunits to be deposited in spillover-like carbonate shoals subjected to oceanic (NE) or wind-driven (SW) surface currents. The small-scale cross bedding could represent the sudden decrease of water velocity at the rear, lee side of the (partially exposed?) shoals.

A reddish karstified calcarenitic unit (3 in Fig. 5) forms the top of this Complex.

\subsubsection{Raised marine terraces and associated terrestrial deposits}

The top of the Complex of Marine Units is a karstified surface with associated red sandy clay ( $\mathrm{K}$ in Fig. 5), that suggests an episode of subaerial exposure. A later marine transgression was responsible for the deposition of the oldest, topographically higher, marine terrace preserved in the Island at an elevation of $55 \mathrm{~m}$ a.s.l., although locally it may reach $60 \mathrm{~m}$ a.s.1. This terrace consists of a $2-4 \mathrm{~m}$ of well-cemented fossiliferous calcarenite (grainstone) and conglomerate with sparite cement, which differentiates it markedly from the Complex of Marine Units.

A large part of Sal Island is occupied by broad surfaces (marine terraces $=\mathrm{T}$ ) underlain by fossiliferous carbonate sediments. The most complete sequence crops out in the centre of the island (Fig. 2, Fig. 6, sections A, B and C) in a broad arch open to the southwest, that extends from Sal airport to Serra Negra forming a staircase-like arrangement of marine terraces resting upon the volcanic rocks, between $55 \mathrm{~m}$ a.s.l. and sea level.

The most complete sequence consists of 16 marine terraces (T1-T16) and unconsolidated beach barriers (Fig. 3). The usual sedimentary succession of a marine terrace consists of a basal wave-cut erosion surface which originated during the transgressive stage, followed upwards by the highstand deposits. In detail, the sedimentary sequence is made up of a basal conglomerate (pebbles and boulders of volcanic rocks) embedded in carbonate
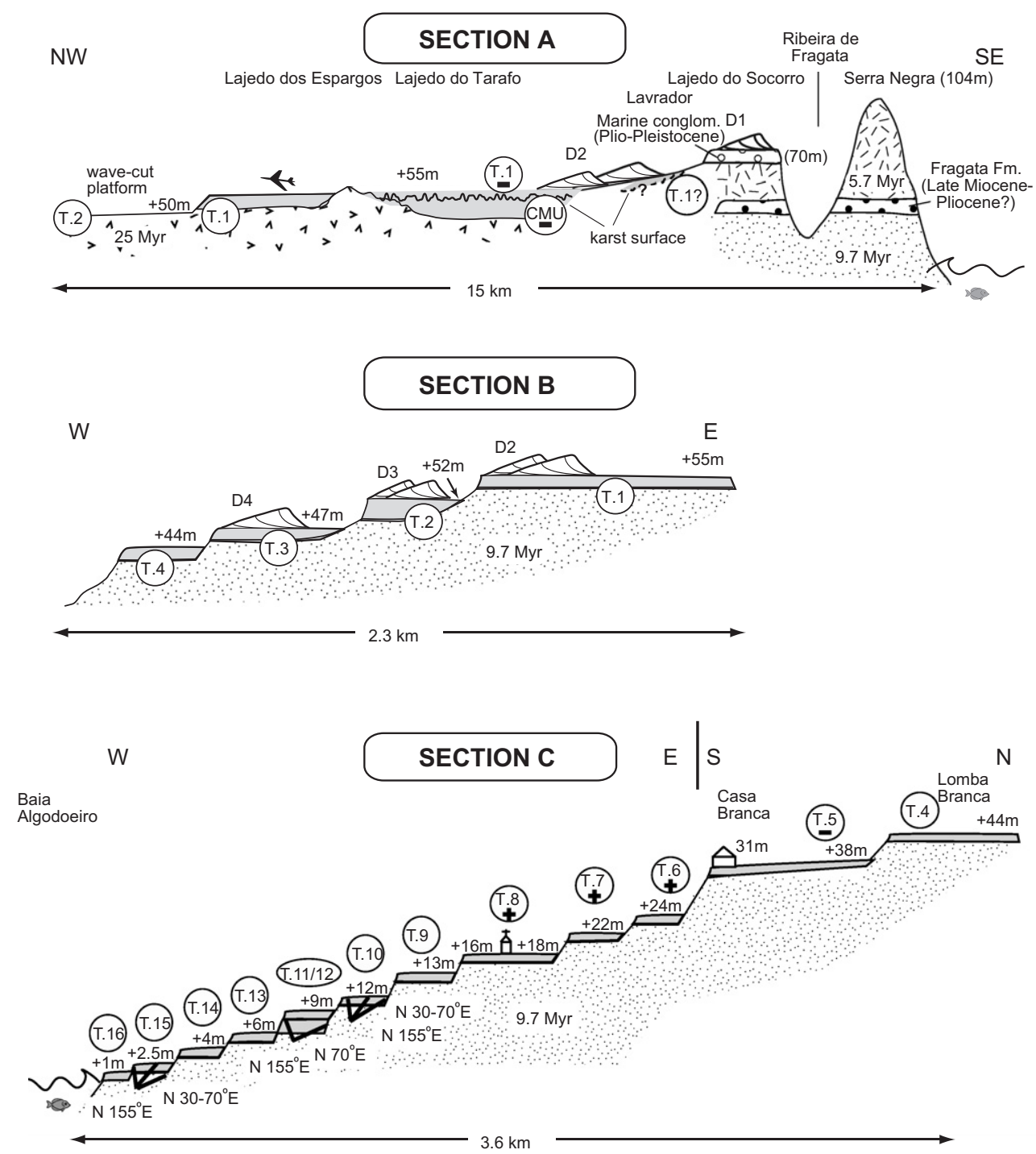

Fig. 6. Synthetic sections of marine terraces (T.1-T.16) and associated aeolian dunes (D1 to D4) overlying volcanic rocks. Main tectonic micro-faults direction $\left(\mathrm{N} 155^{\circ} \mathrm{E}\right)$ and palaeomagnetic results $( \pm$, normal /reverse) have been indicated. (See Fig. 2 for location.) 
mud which consists of the remains of red coralline algae (Melobesia). Grain size tends to decrease upwards passing into skeletal calcarenite (Fig. 7). Sedimentary structures include wave-ripple cross bedding and cross lamination, parallel lamination gently $\left(5^{\circ}\right)$ inclined seaward (Fig. 8), and various types of burrowing. These are interpreted as nearshore (upper shoreface) and foreshore deposits. The average thickness of terrace deposits does not surpass $3 \mathrm{~m}$.

One of the terraces is actually a vertical stacking (superposition) of terrace deposits T.11 and T.12 (Fig. 3) separated by an erosion surface. T.11 deposits are crossed by numerous joints and small fractures that do not continue into T.12. The basal conglomerate of T.12 includes fragments derived from the underlying terrace. Out of the mapped area, these two terraces can be easily separated.

The northern part of the island was affected by recent volcanic activity $(\sim 0.6 \mathrm{Ma})$. Here, the oldest representative of the stair-like sequence of marine terraces occurs at elevations of 25-26 ma.s.1. near Morinho do Filho and Monte Leste (Fig. 2). Sheet flow deposits from these mountains have largely obliterated the marine deposits which are reduced to discontinuous patches. However, water wells excavated in the area allow observation of at least $2 \mathrm{~m}$ of fossiliferous (molluscs and corals) calcarenites (Fig. 9). Fossils in the oldest units are S. bubonius and $A$. senilis, which are recrystallized or reduced to moulds. Nevertheless, Lecointre $(1962,1963)$ reported the presence of $S$. bubonius and A. senilis in the three terraces that he
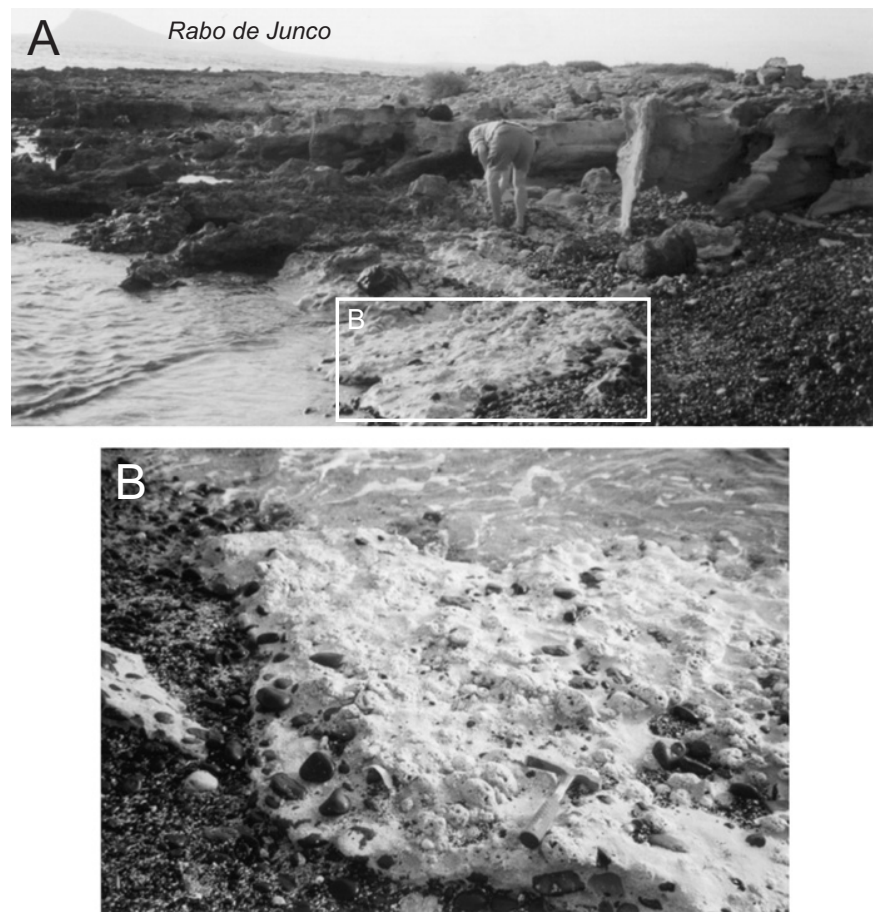

Fig. 7. Sedimentary facies (conglomerates and calcarenites) of T.15 (OISS 5e) in Ribeira Fonte do Estado (south Baia da Murdeira). (A) Panorama of outcrop and vertical joints referred to in text. (B) Close up of the basal conglomeratic facies.

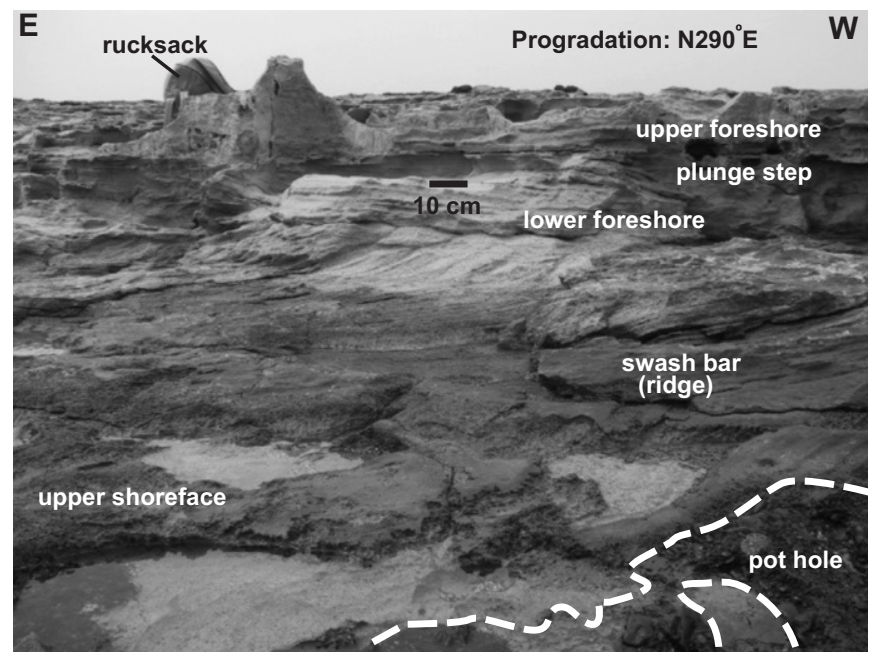

Fig. 8. Sedimentary facies of coastal deposits in the upper part of T.15 (OISS 5e) at Cascalho. Note a pot hole filled with Holocene marine sediments in the lower right corner.

distinguished (at $55-13 \mathrm{~m}, 8-7 \mathrm{~m}$, and $5 \mathrm{~m}$ to current sea level). Due to the fact that Lecointre did not present a map for the terraces, we could not recognize them in those mapped in Fig. 3.

A detailed paleontological study is presently underway, but we report some preliminary findings here. The largest number of identifiable species was collected in the more recent terraces on the southern half of the Island. Strombus latus Gmelin (S. bubonius Lamark), A. senilis Linné, Conus ermineus Born (C. testudinarius Martini), Cardita senegalensis Reeve, Harpa rosea Lamark, Favia fragum Esper, and Siderastrea radians Pallas are found in deposits as old as those of terrace T.5, particularly at the Casa Branca site (Fig. 10A and B) that is one of the best outcrops in the area. However, the richest faunas are associated with terraces T.13, T.14, T.15 and T.16 where, besides the former species, there are also abundant Polinices lacteus Guilding, Cantharus viverratus Kiener ( $C$. variegatus Gray), Cardita senegalensis Reeve, the hydrocoral Millepora sp., and the corals Favia fragum Esper and Siderastrea radians Pallas, of which $S$. radians is the only one showing constructional capability.

The study and comparison of present-day molluscs with those found in six outcrops of coastal deposits at elevations between high tide and $5 \mathrm{ma.s.l}$. (García-Talavera, 1999) adds a longer list of species. This author concluded that "fossil" and "present" faunas are similar and, besides many endemic species, include species of the Mediterranean-Lusitanian and the western African tropical provinces (Garcia-Talavera and Bacallado, 1981; Rolán, 2005). The tropical amphi-Atlantic species are mainly represented by $C$. ermineus and $P$. lacteus. Conus ermineus is common on the western African coasts from the Sahara to Angola, and on the eastern American coasts of Brazil, Antilles, Central America, Gulf of Mexico and the Bahamas (Callapez and Ferreira Soares, 2000). 

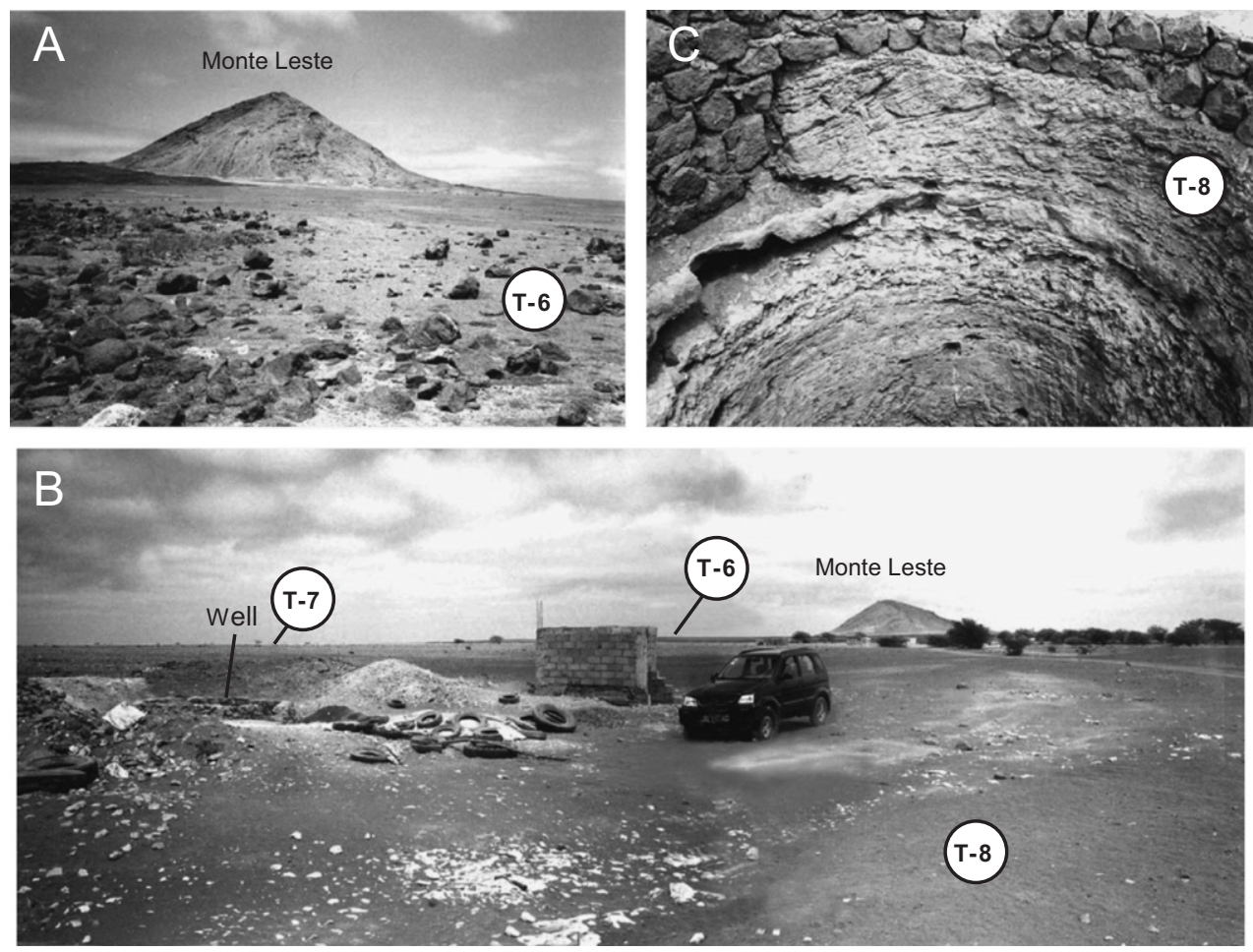

Fig. 9. Marine terraces in the northern Sal Island (A) Poorly-exposed calcarenite deposits of T.6 with Monte Leste in the background. (B) T.6, T.7 and T.8 near Terra Boa, and the water well where the internal structure of terraces could be observed. (C) Close-up of the upper part of water well with marine terrace T.8. All terraces overlie the volcanic rocks aged $0.6 \mathrm{Ma}$

Polinices lacteus is one of the best examples of tropical amphi-Atlantic gastropods found from Mauritania to Angola in the African side, the islands of Madeira, Canary and Santa Helena in the Atlantic Ocean, and from the Brazilian to the Caribbean coasts in America (Callapez and Ferreira Soares, 2000). All these species have been found in Last Interglacial deposits on the Mediterranean, together with S. bubonius (Cuerda, 1989).

The oldest marine terraces have associated aeolian dunes (Figs. 3 and 6) made up of well sorted, cemented sandstones with moulds of terrestrial gastropods (Helix sp). Four dune systems (D1 to D4) have been distinguished and mapped. Past prevailing wind directions seem to have been parallel to the present trade winds, although the internal structure of dunes is poorly preserved and not well exposed. Holocene parabolic, longitudinal and transverse dune systems and sheet sands cover a large part of the southern tip of the island (Fig. 3).

Three systems of alluvial fans related to marine terraces have been distinguished and mapped (Fig. 3). The oldest of these systems covers terraces T.7 and T.8, and it is cemented. A younger system, only cemented at the surface, cuts through terrace T.9, and it is certainly younger than T.9, but it is not easy to determine precisely which terraces it is related to. Therefore, its position in the stratigraphic sequence (Fig. 3) is uncertain. The youngest, most recent system is widespread despite its minimal thickness. It is made up of loose gravel with rounded and angular clasts.
The superficial distribution of marine terraces and alluvial fans, coupled with the differences in elevation (however small) of terraces, suggest that the island was cut by a $\mathrm{N} 30^{\circ}{ }^{\circ} \mathrm{E}$ fracture with vertical movement which separated a northern uplifting block and a southern subsiding block that housed the beach barrier and lagoon systems.

Three systems of joints and microfractures $\left(\mathrm{N} 10^{\circ}-30^{\circ}\right.$, $\mathrm{N} 70^{\circ}$ and $\mathrm{N} 150^{\circ}-160^{\circ} \mathrm{E}$ ) are recognized, especially in the area south of Santa Cruz Hermitage (Fig. 3). These cut the deposits of terrace T.10 (Fig. 11) and also those of the younger terrace (T.15). In the latter case, differential cementation around fractures makes them protrude prominently. Cross-cutting relations suggest that the fractures oriented $\mathrm{N} 150^{\circ}-160^{\circ} \mathrm{E}$ were the last to form (Fig. 12).

\subsection{Age constraints}

\subsubsection{Paleomagnetic data}

Given the volcanic-sedimentary sequence in Sal Island, paleomagnetic studies were carried out on the Complex of Marine Units and the marine terraces of the most complete sequence in southern Sal Island (Fig. 2). In addition, we also sampled the youngest volcanic units (Monte Grande Formation, dated as $\sim 0.6 \pm 0.2 \mathrm{Ma}$ by Torres et al. (2002a) near Punta Norte, because it is the substratum of terrace T.6 (Figs. 2 and 3). 

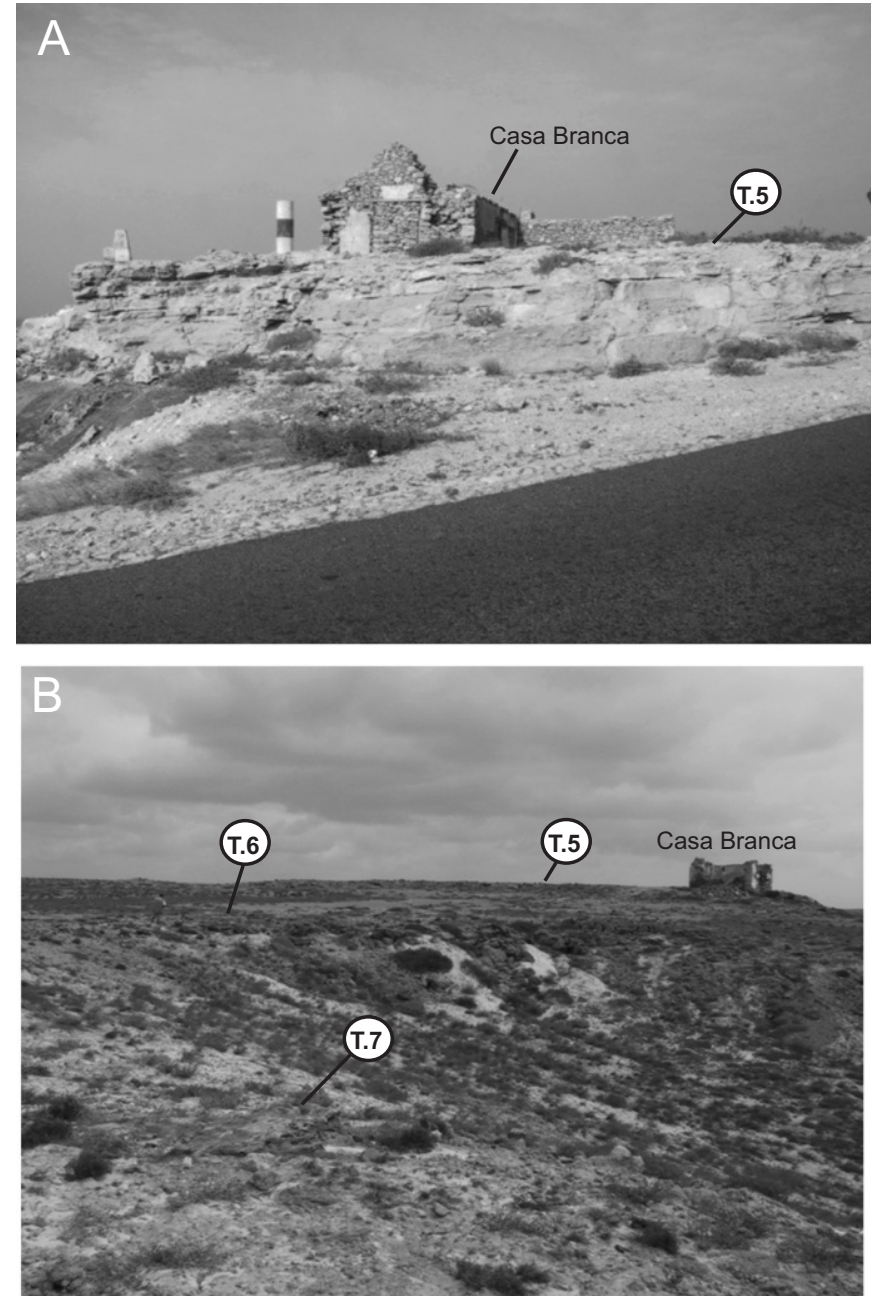

Fig. 10. Casa Branca (A) Low-angle cross bedding of south-west prograding foreshore facies, terrace T.5. (B) Panorama of the staircaselike arrangement of terraces T.5-T.7.

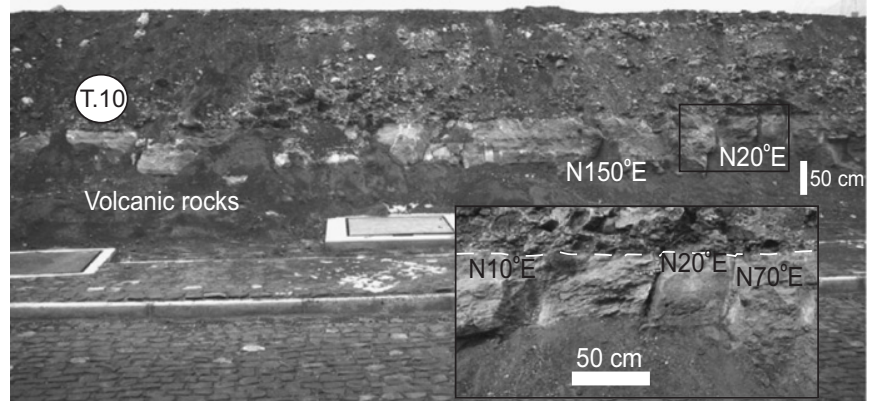

Fig. 11. Joint and microfault systems in T.10 near bench mark 12 (between Ponta Preta and Santa Cruz ermitage).

Some samples of marine deposits, mainly calcareous in composition, contain significant amounts of volcanic clasts with high natural magnetic remanization intensity. This results in a high dispersion of the paleomagnetic measurements such that, although a magnetic polarity can be

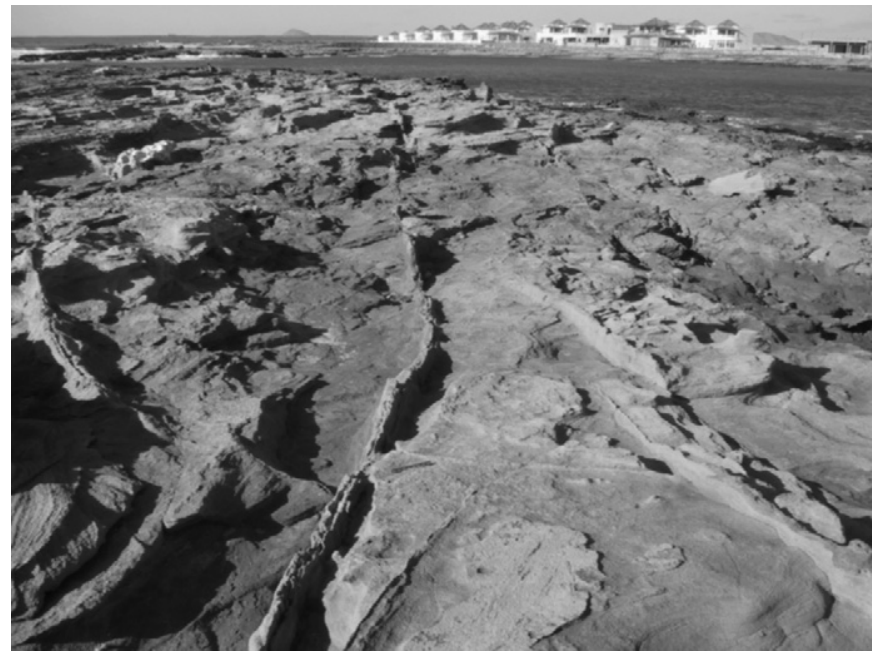

Fig. 12. Joint systems in T.15 (OISS 5e), Cascalho.

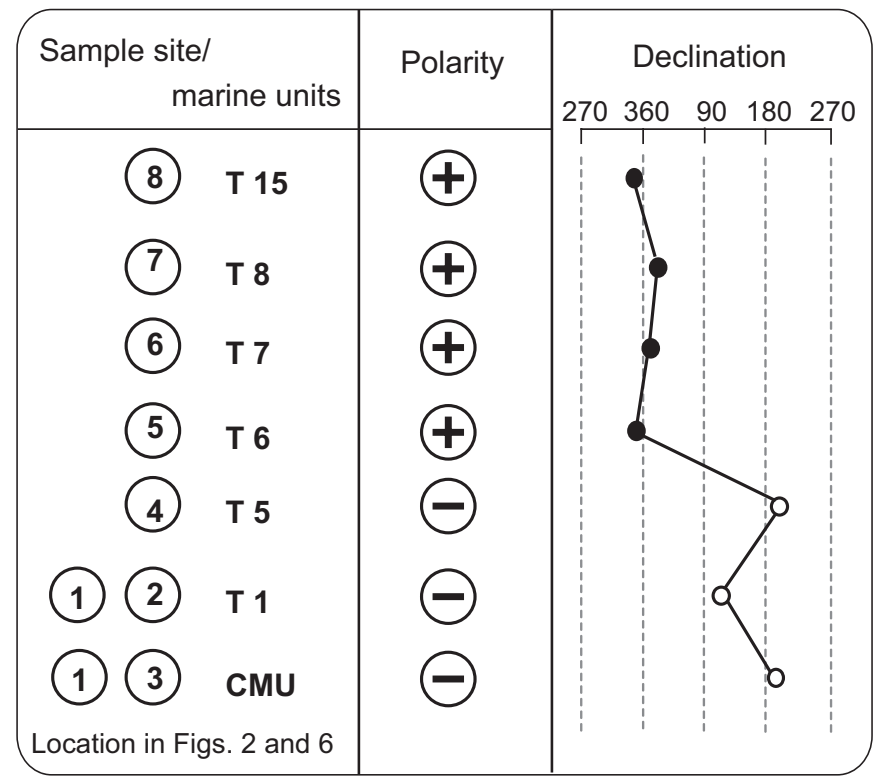

Fig. 13. Paleomagnetic data.

established, it becomes very difficult to accurately measure the direction of the virtual geomagnetic pole. The polarity results have been summarized in Fig. 13.

Samples collected (Figs. 2 and 6, sections A and C) from the CMU, terrace T.1 (2 samples in Lajedo do Tarafo) and terrace T.5 (Casa Branca) suggest a reverse polarity. In contrast, samples from terraces T.6-T.8, all of which are inset into T.5 at Casa Branca (Fig. 10B), have a normal polarity. A normal, positive polarity was also measured in terrace T.15 near Cascalho (Fig. 8). The polarity of volcanic Monte Grande Formation is normal, which is concordant with the $\mathrm{K} / \mathrm{Ar}$ age of $0.6 \pm 0.2 \mathrm{Ma}$ (Torres et al., 2002a) assigned to this Formation.

\subsubsection{U-series data}

Data on coral samples broadly define four sets of values identified by the letters $\mathrm{A}$ to $\mathrm{D}$ in Table 1 and relevant 
figures. Group A corresponds to samples from unconsolidated deposits of very late Holocene age. Group B represents samples dating from the Last Interglacial (OISS 5e), with some outliers corresponding to corals showing $20 \%$ or more calcite contents (Fig. 14). Such recrystallized samples do not show significant changes in their total $\mathrm{U}$ content (Table 1) and their ${ }^{234} \mathrm{U} /{ }^{238} \mathrm{U}$ activity ratios still show a near-marine signature (Fig. 14). Complementary measurements on mollusc shells and hydrozoan skeletons (Millepora sp.), most likely from Last Interglacial age, based on field and geochemical evidence, were performed in order to better constrain the isotopic signature of any diagenetic uranium (e.g., Kaufman et al., 1996) in such deposits. They depict ${ }^{234} \mathrm{U} /{ }^{238} \mathrm{U}$ activity ratios in the 1.12-1.2 range, thus accounting for the relatively low excess in ${ }^{234} \mathrm{U}$ shown by the partly recrystallized corals. Otherwise, most Last Interglacial corals are relatively well clustered but nonetheless depict a slight trend above the theoretical ${ }^{234} \mathrm{U} /{ }^{238} \mathrm{U}$ value expected for "marine uranium" in this range of age (Fig. 15). Several processes may

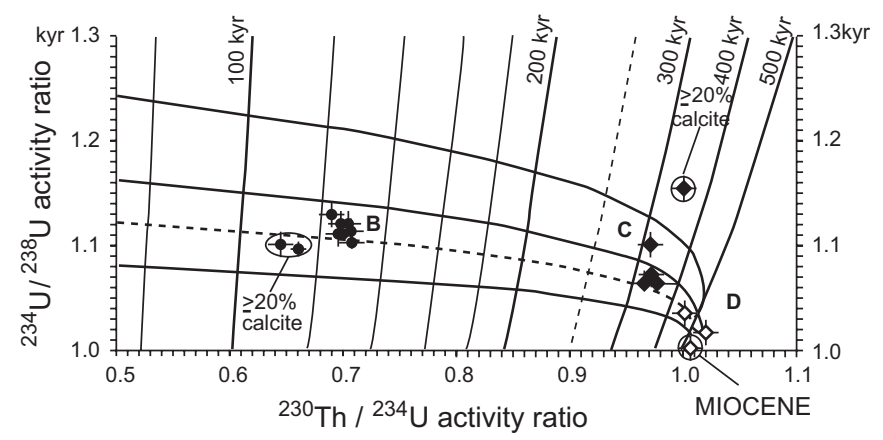

Fig. 14. U-series abacus showing the distribution of sample groups B, C and $\mathrm{D}$ (see text).

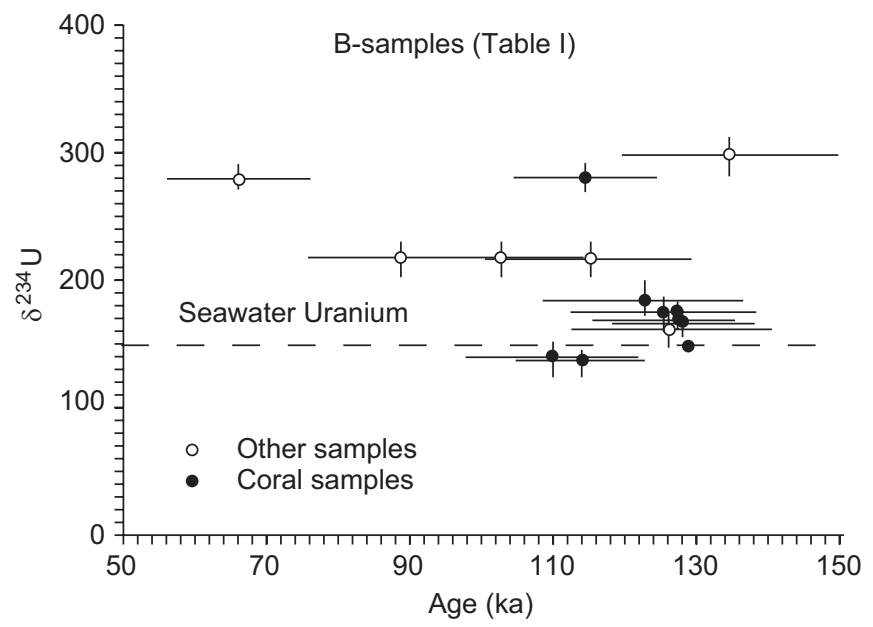

Fig. 15. Isotopic composition (activity ratio) of uranium vs. calculated ages in samples assigned to the Last Interglacial (B samples from Table 1). Even coral samples (with 2-3 ppm of authigenic U) show some scatter of values indicating a relatively open geochemical behaviour. See Chen et al. (1986) or Delanghe et al. (2002) with reference to the isotopic signature of seawater uranium. account for such a trend (e.g., Thompson et al., 2004), but their impact on the calculated ages seems of minor incidence here, as illustrated by seriate measurements in one $S$. radians sample showing three growth phases, the last two of which are separated by a stage of intense bioerosion (see Fig. 16). In this sequence, despite the fact that the outlier part of the coral shows a relatively high calcite content (about 10\%), all ages are concordant within their $2 \sigma$-standard deviation. Stable isotope compositions in this multiphase coral are also well clustered, suggesting a narrow range of environmental conditions. The low $\delta^{18} \mathrm{O}$ values (Table 1), compared with those of Millepora samples, suggest growth in shallow warm pools of waters (Table 2).

Finally, sample groups $\mathrm{C}$ and $\mathrm{D}$ represent clusters in the $320-340 \mathrm{Ka}$ range, and near ${ }^{230} \mathrm{Th} /{ }^{234} \mathrm{U}$ secular equilibrium, respectively (Fig. 13). Here again, most samples suggest some ${ }^{234} \mathrm{U}$-excess, thus are relatively open systems. One cannot totally discard the possibility that group $\mathrm{C}$ represents an enhanced diagenetic impact on older samples, possibly from group D. However, the relatively narrow isotopic cluster (Fig. 13) and U-content (2.7 ppm) in group C samples, compared with group D samples, would be compatible with a tentative OIS 9 assignment. With one exception, all $S$. radians samples from these two groups show $\delta^{18} \mathrm{O}$ values not unlike those of sample S03 68-2 (Table 1), thus suggesting similar growth conditions and a relatively good preservation of the original isotopic signature.

\subsubsection{Radiocarbon data}

Two samples have been collected from the lowermost terraces: one in the calcarenites with Ostrea strentina (T.15, ${ }^{14} \mathrm{C}$ age $24,870 \pm 960 \mathrm{yr}$ BP, certainly a minimum age) at Cascalhos (Fig. 8); a second in the conglomeratic deposits
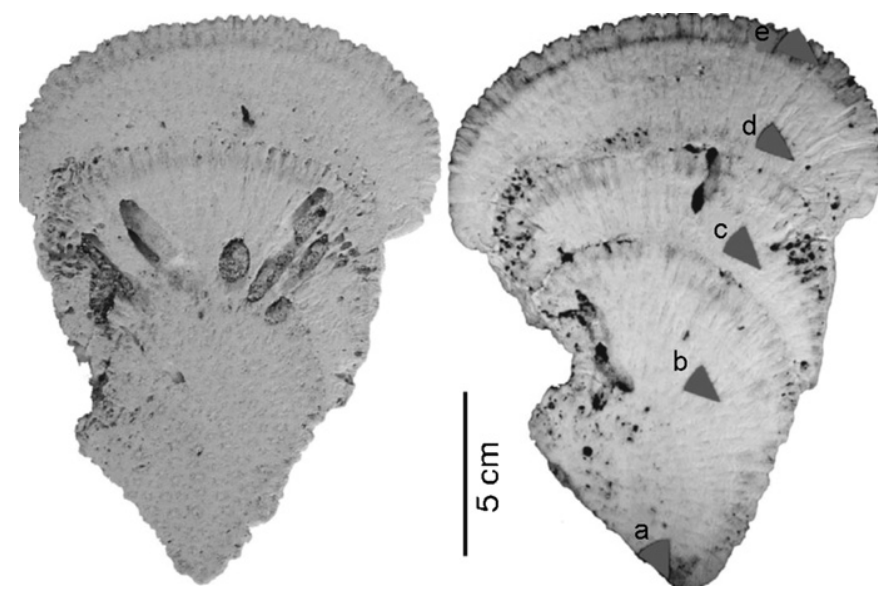

Fig. 16. Sample S0-68 (Siderastrea radians) from the basal conglomerate of T.15 at the same locality of Fig. 7. Samples for U-series measurements have been taken in the lower (a, b), middle (c) and upper (d, e) growth stages (see corresponding results in Table 1). Note (left) that bioerosion was intense following the second stage thus suggesting minimum time interval for the coral growth interruption, but the persistence of relatively calm conditions to allow growth stage 3 to follow on top of the coral. 
Table 2

Location, topographic elevations, and ages deduced from field and isotopic data for samples presented in Table 1, reworked sample

\begin{tabular}{|c|c|c|c|c|c|c|}
\hline Sample \# & Locality & $\begin{array}{l}\text { Elevation } \\
\text { (m a.s.1.) }\end{array}$ & $\begin{array}{l}\text { Calcul. age } \\
(\mathrm{ky})\end{array}$ & \pm & Group & $\begin{array}{l}\text { Chronology of marine terraces }(\mathrm{T}) \\
\text { and beach barriers, deduced from } \\
\text { isotopic and field data (see Fig. } 3 \text { ) }\end{array}$ \\
\hline \multicolumn{7}{|l|}{ Coral samples } \\
\hline S03-64 & $\begin{array}{l}\text { Ponta Preta (Baia } \\
\text { Algodoeiro) }\end{array}$ & 0 & $0.18^{*}$ & \pm 0.013 & A & Holocene \\
\hline S03- 57 & Ponta do Leme Velho & 1.8 & 114.8 & \pm 4 & $\mathrm{~B}$ & T.15 \\
\hline S03-65 & Santa Maria Bay & 2.5 & 122.9 & $+3.6 /-3.4$ & $\mathrm{~B}$ & T.15 \\
\hline S03-68-1 & South Baia da Murdeira & 0 & 114.2 & $+1.6 /-1.5$ & B & T.15 \\
\hline S03-68-2-e & South Baia da Murdeira & 0 & 125.7 & $+3.2 /-3.1$ & B & T.15 \\
\hline S03-68-2-d & South Baia da Murdeira & 0 & 127.8 & \pm 2.7 & $"$ & $\mathrm{~T} .15$ \\
\hline S03-68-2-c & South Baia da Murdeira & 0 & 125.8 & $+2.6 /-2.5$ & $"$ & T.15 \\
\hline S03-68-2-b & South Baia da Murdeira & 0 & 128.5 & $+3.7 /-3.5$ & $"$ & T.15 \\
\hline S03-68-2-a & South Baia da Murdeira & 0 & 129.2 & $+4.0 /-3.8$ & $"$ & T.15 \\
\hline S03-69 & South Baia da Murdeira & 0 & 110.2 & \pm 2.5 & B & T.15 \\
\hline S02-8 & $\begin{array}{l}\text { Ponta Preta (Baia } \\
\text { Algodoeiro) }\end{array}$ & 3 & $>>$ & & & T.14 \\
\hline S02-9 & $\begin{array}{l}\text { Ponta Preta (Baia } \\
\text { Algodoeiro) }\end{array}$ & 6 & 312 & $+26 /-21$ & $\mathrm{C}$ & $\mathrm{T} .13$ \\
\hline S03-54 & $\begin{array}{l}\text { Santa Maria-Ponta do } \\
\text { Leme Velho }\end{array}$ & 5 & 322 & $+35 / 26$ & $\mathrm{C}$ & $\mathrm{T} .13$ \\
\hline S03-55 & $\begin{array}{l}\text { Ponta do Leme Velho-- } \\
\text { Pta. Jalunga }\end{array}$ & $1.25^{* *}$ & 343 & $+73 /-43$ & $\mathrm{C}$ & $\mathrm{T} .13$ \\
\hline S03-73 & Baleia & 5.5 & 330 & $+24 /-19$ & $\mathrm{C}$ & $\mathrm{T} .13$ \\
\hline S03-70 & South Baia da Murdeira & 12 & $>>$ & & $\mathrm{D}$ & T.10 \\
\hline S03-77 & $\begin{array}{l}\text { Ponta Vermelha-Ponta } \\
\text { Palona }\end{array}$ & 7 & $>>$ & & $\mathrm{D}$ & T.15 \\
\hline S03-79 & $\begin{array}{l}\text { Ponta Palona-Ponta } \\
\text { Norte }\end{array}$ & 2 & $>>$ & & $\mathrm{D}$ & Miocene \\
\hline \multicolumn{7}{|c|}{ Other measurements } \\
\hline S03-58 & Ponta Jalunga & 0 & Modern & & A & Holocene \\
\hline S03-51 & Ponta do Leme Velho & 0 & $0.3^{*}$ & \pm 0.2 & A & Holocene \\
\hline S03-52 & $\begin{array}{l}\text { Santa Maria-Ponta do } \\
\text { Leme Velho }\end{array}$ & 0.25 & $1.7^{*}$ & \pm 0.1 & A & Holocene \\
\hline S03-74 & Baleia & 7.5 & $103.0^{*}$ & $+5.4 /-4.6$ & B & $\mathrm{T} .15$ \\
\hline S03-61 & $\begin{array}{l}\text { NW Cemetery (Santa } \\
\text { Maria) }\end{array}$ & 2 & 126.6 & $+5.1 /-4.9$ & $\mathrm{~B}$ & $\mathrm{~T} .15$ \\
\hline S03-62 & $\begin{array}{l}\text { NW Cemetery (Santa } \\
\text { Maria) }\end{array}$ & 1.5 & 135.0 & $+8.5 /-7.9$ & $\mathrm{~B}$ & T.16 \\
\hline S03-74 & Baleia & 7.5 & $89.1^{*}$ & $+2.3 /-2.2$ & $\mathrm{~B}$ & T.15 \\
\hline S03-57 & Ponta do Leme Velho & 1.8 & $66.4^{*}$ & \pm 2.5 & $?$ & T.15 \\
\hline $\mathrm{S} 03-2$ & Santa Maria Bay & 1.5 & & $+3.7 /-3.6$ & B & T.16 \\
\hline S03-66 & South Baia da Murdeira & 4 & 340 & $+28 /-23$ & $\mathrm{C}$ & $\mathrm{T} .13$ \\
\hline
\end{tabular}

*Ages requiring corretion due to detrital contents.

**Elevation measured at the sea front of the marine terrace.

with $S$. bubonius (T.16, ${ }^{14} \mathrm{C}$ age $\left.>41,430 \mathrm{yr} \mathrm{BP}\right)$ at Ponta do Leme Velho (Fig. 3). ${ }^{14} \mathrm{C}$ data suggest a pre-Holocene age for these terraces.

We also sampled the aeolian systems overlying the oldest modern beach barrier near the Ponta do Sinó Lighthouse (1500 m SW of Santa María, Fig. 3). The age of a shell of the terrestrial gastropod Zootecus insularis is $5,940 \pm 50{ }^{14} \mathrm{C}$ yr BP (6775-6750 cal yr BP).

\subsubsection{Chronological framework}

In the Legend of the geomorphologic map (Fig. 3), relative chronology is based on regional stratigraphic data, isotopic and palaeomagnetic analyses. However, assignment of a given terrace to a specific OIS is not easy with the present data for those older than T.13, here assigned tentatively to the OIS 9. The Last Interglacial (OIS 5) records two high sea levels represented by terraces T.15 and T.16 (Fig. 3). Terrace T.15 has a clear OISS 5e age based on U-series measurements (Table 1), however the few Useries data from T.16 impede assignation to a specific Last Interglacial substage, However, field data suggest an age slightly more recent for T.16, as it occurs inset into T15. This suggests a fall in sea level followed by a new rise that did not reach the former elevation but excavated the "micro-cliff" separating these two terraces observed west of Santa Maria Cemetery (Fig. 3). Small oscillations in sea level during the final phase of sedimentation of unit T.16 favoured the formation of a barrier that enclosed a lagoon. 
The overall trend in this period (OISS5e) was towards a relative fall in sea level. Additional examples of two superposed, offlapping prograding units inside the OIS 5e deposits have been observed, for example around Cascalho-Murdeira, on the western façade of Sal Island. These are separated by an erosional surface with basal conglomerate that overlies the burrowed berm facies of the underlying unit (the one pictured in Fig. 8; the upper one is not visible in that photograph as it crops out closer to the sea).

Taking this into account, along with the low elevation of the shoreline angles of T.15 ( $\leqslant 2.5 \mathrm{~m}$ a.s.1.), and T.16 $(1 \mathrm{~m}$ a.s.1.), and the absence of major erosional surfaces or intervening terrestrial deposits separating T.15 and T.16, one is lead to suggest a double highstand inside OISS 5e, which would include both terraces, rather than assigning T.16 to either OIS $5 \mathrm{c}$ or $5 \mathrm{a}$.

As in Canary Islands (Zazo et al., 2002), the terrace corresponding to OIS 7 has not been positively identified, probably due to both the scarcity of dating and the low altitude reached by the Last Interglacial deposits in both archipelagos $(\leqslant 2.5 \mathrm{~m})$. Nevertheless, T.14 could be a possible candidate.

\subsection{Some palaeoecological information deduced from molluscs}

The species $S$. bubonius, C. testudinarius, C. viverratus, and $C$. senegalensis are a part of "Senegalese warm fauna", first defined by Gignoux (1913) and Issel (1914). This faunal assemblage is particularly interesting because it migrated to the Mediterranean Sea during some of the Quaternary interglacials, namely the Last Interglacial (Hearty et al., 1986; Cuerda, 1989; Hillaire-Marcel et al., 1996; Goy et al., 1993; Zazo et al., 2003). During the Last Interglacial, some of these species lived in the coasts of Azores (García-Talavera, 1987, 1999; Avila, 2000) and Canary Islands (Meco et al., 1997, 2002; Zazo et al., 2002, 2003) that are a part of the Macaronesia biogeographical region. The Senegalese warm fauna is extinct nowadays in the coast of the Mediterranean Sea, Azores and Canary Islands.

The cited species, and particularly S. bubonius (S. latus), live nowadays on sandy bottoms rich in algae (the main diet of Strombus) in sheltered realms such as bays and lagoons. They require minimum depths of $4 \mathrm{~m}$ (Morri et al., 2000), with sea surface temperatures between 21 and $26^{\circ} \mathrm{C}$, mean annual temperature $23.5^{\circ} \mathrm{C}$, and salinity 35 p.s.u. (practical salinity units) (NOAA-WOA, 2001). Our data indicate that such palaeoecological conditions existed in Cape Verde during the Middle and Late Pleistocene (OIS 9 and OISS 5e), as we have found large accumulations of $S$. bubonius shells both in Late Pleistocene (fossil) and present beaches and beach barriers of the southern (Santa Maria Bay) and south-eastern (between Ponta do Leme Velho and Ponta Jalunga) coasts of Sal Island. Thus, during the Last Interglacial, and at least one earlier interglacial, waters around Sal Island were at least as warm as they are nowadays.

Therefore, it seems logical to assume that larvae of these species were transported by the oceanic superficial currents to distances exceeding $3000 \mathrm{~km}$ and reached the Mediterranean Sea. We suggest that the Cape Verde Archipelago was one of the source areas of the "Senegalese fauna". These currents are the Pleistocene ancestors of the present Subtropical North Atlantic Gyre formed by Gulf, Azores, Canary and North Equatorial currents, but with different trajectories, surface temperatures, intensities and velocities. Similar migrations to the north of tropical waters have been described in the western Atlantic Ocean (Muhs et al., 2002) during the Last Interglacial.

\subsection{Paleo-sea levels and vertical movements.}

The elevation reached by sea level during OISS $5 \mathrm{e}$ is relatively well constrained because it is represented by the most ubiquitous and well-preserved set of emergent littoral features around many coastlines of the world. However, there are noticeable divergences concerning the number of highstands that occurred during the Last Interglacial. Data on the relative sea-level elevation during OISS $5 \mathrm{e}$ on tectonically stable coasts of Western Australia (Stirling et al., 1998), located far from the former ice sheets, suggest a sea-level highstand from $128 \pm 1$ to $116 \pm 1 \mathrm{Ka}$ at least 3 m.a.s.l during this time. A sea level elevation of about $5 \mathrm{~m}$ a.s.l. during the peak of OISS 5e (132-120 Ka) has been suggested by Chen et al. (1991) in the Bahamas and by Muhs et al. $(2002,2004)$ in Bermuda Island and Florida. However, two different highstands have been stated by Hearty (2002) in Bermuda: the first one, recorded at about $2.5 \mathrm{~m}$ a.s.1., developed between 132 and $125 \mathrm{Ka}$, and the second one, being registered by a notch and small rubble benches at $6 \mathrm{~m}$ a.s.l. and possibly as high as $9 \mathrm{~m}$.a.s.l., generated between 120 and $115 \mathrm{Ka}$. Two or three marine terraces have been recorded in tectonically actives areas of Haiti (Dumas et al., 2006) and Barbados (Schellmann and Radtke, 2004) respectively. In Haiti, these two marine terraces developed between 130.5 and $122 \mathrm{Ka}$ with paleosea-level at $5 \mathrm{~m}$ a.s.l. for the older one and $2.7 \mathrm{~m}$ a.s.l for the younger one. In Barbados, Schellmann and Radtke (2004) suggested palaeosea-levels at 6, $4 \mathrm{~m}$ a.s.1., and $-8 \mathrm{~m}$ below sea level (b.s.l.), about 132, 128 and $118 \mathrm{Ka}$, respectively. In eastern Atlantic, geomorphologic and stratigraphic data from Canary Islands suggest the existence of two highstands between 0 and $2 \mathrm{~m}$ a.s.l., recorded as clastic marine deposits (shoreface and foreshore beach facies) with ${ }^{230} \mathrm{Th}$ ages around $118 \pm 16 \mathrm{Ka}$. They are separated by intervening alluvial or colluvial deposits but, unfortunately, neither U-series ages nor amino-acid data allowed to discriminate between them (Zazo et al., 2002).

Referring to OISS $5 \mathrm{c}(\sim 100 \mathrm{Ka})$, most data from both stable (Stirling et al., 1998, etc.) and unstable (Schellmann et al., 2004; Dumas et al., 2006) Atlantic coasts suggest that sea level at this time was several metres (the proposed 
figures range between -8 and $-25 \mathrm{~m}$ ) lower than the present sea level.

Concerning the OISS $5 \mathrm{a}(\sim 80 \mathrm{Ka})$, a relative highstand close or slightly above present sea level has been stated by Hearty and Kaufman (2000) in the Bahamas, by Muhs et al. (2002) in Bermuda, and by Ludwig et al. (1996) in Florida and Bermuda. U-series coral ages from the US Atlantic Coastal Plain (Wehmiller et al., 2004) suggest a paleo sea level slightly above present at $80 \mathrm{Ka}$. In Barbados, Schellmann et al. (2004) recognized a double sealevel oscillation around $85 \mathrm{ka}$ and $77-74 \mathrm{Ka}$, with palaeo sealevels at ca -21 and $-19 \mathrm{~m}$ b.s.l. In Haiti, Dumas et al. (2006) also distinguished two sealevel highstands: the older around $\sim 82 \mathrm{Ka}$ with palaeo sealevel $\sim-11 \mathrm{~m}$ b.s.l., and a younger episode at $\sim 76 \mathrm{Ka}$ with palaeo sea-level $\sim-13 /-10 \mathrm{~m}$ b.s.l.

The exact sea levels reached during OIS 7 highstands are still poorly constrained. A sea level elevation a few metres $(\sim 2 \mathrm{~m})$ above present during OIS 7 has been suggested in tectonic stable coasts of the Atlantic as Bermuda (Hearty, 2002; Muhs et al., 2002) and Florida (Muhs et al., 2004), the Bahamas (Hearty and Kaufman, 2000). These data conflict with those obtained by Bard et al. (2002) in Argentarola Cave (Italy), a region considered tectonically stable based on the continuous elevation $(\sim 5-6 \mathrm{~m})$ of the OISS 5e deposits, which suggests a palaeosea-level between -9 and $-18 \mathrm{~m}$ b.s.1. $(202-290 \mathrm{Ka})$.

Studies from Henderson Island, in the equatorial Pacific Ocean (Stirling et al., 2001) suggest that sea level was a few meters higher than the present during OIS 9 at $\sim 330 \mathrm{Ka}$. The number and elevation of the sequence of marine terraces at Sal Island are similar to those found in Canary Islands (Zazo et al., 2002, 2004). Geological field data and morpho-sedimentary analysis supported by $\mathrm{U}$-series, $\mathrm{K} / \mathrm{Ar}$, and ${ }^{14} \mathrm{C}$ dating, and amino-acid racemization data allowed to identify the marine deposits corresponding to OIS 9 which, in Lanzarote Island occur at elevations $0-1 \mathrm{~m}$ a.s.1., and are covered by Last Interglacial deposits. The marine terrace corresponding to OIS 7 has not been positively identified, although some morphological evidences suggest that it may be present along the south-western coast of Fuerteventura Island. As said before, Zazo et al. (2002) recognized two highstands inside the peak of the Last Interglacial (OISS 5e).

In Sal Island, the marine terraces corresponding to the Last Interglacial are T.15 and T.16. U-series data assign an OISS 5e age $(\sim 129-110 \mathrm{Ka})$ to terrace T.15 but, as said before, field data lead us to also include T.16 in OISS 5e.

The available Th-ages for T.13 agree with the assigned OIS 9 age (at $+6 \mathrm{~m}$ ); therefore, it seems probable that T.14 may represent OIS 7 .

The elevations of the younger terraces suggest that Sal Island can be considered stable, or slightly subsiding, at least since the Last Interglacial. In contrast, the many marine terraces deposited between $600 \mathrm{Ka}$ (the age of the more recent volcanism in Sal) and $330 \mathrm{Ka}$ point to an upward movement, a trend that can be extended to a large part of the Quaternary if the terraces older than the prerecent volcanic activity in the island are also considered. This change in the vertical trend has also been reported in the Canary Islands (Zazo et al., 2002).

\section{Conclusions}

This paper presents the first geomorphologic map of Quaternary landforms and associated marine and terrestrial deposits in Sal Island (Cape Verde Archipelago). Up to 16 marine terraces (T.1 to T.16) have been distinguished. Terraces occur in a staircase-like arrangement ranging in elevation from 55-60 $\mathrm{m}$ a.s.l. down to present sea level.

Pleistocene marine terraces and Holocene beach-barrier and lagoon systems are well exposed along the southern coast, which is sheltered from the prevailing NE trade winds. In contrast, narrow erosional platforms with little associated deposits are the norm along the more exposed northern coast.

The sequence of terraces is complete in the southern part of the island, whereas in the northern half, where volcanic activity took place around $0.6 \mathrm{Ma}$, the oldest preserved terrace is T.6 $(\sim 25 \mathrm{~m}$ a.s.1.)

U-series measurements, mainly in coral cobbles, allow distinguishing deposits from the Last Interglacial age (OISS 5e), characterised by geometry (staircase arrangement) and sedimentary facies (interbedded lagoon deposits) that suggest the occurrence of two highstands (T.15 and T.16), the older with a palaeo seal-evel at $2.5 \mathrm{~m}$ a.s.l. higher than the younger at $1 \mathrm{~m}$ a.s.1. Terrace T.13 (at $6 \mathrm{~m}$ a.s.1.) yielded ages in the range of OIS 9.

The still ongoing analyses of fossil faunas indicate that the most characteristic (Strombus bubonius) species of the so-called "Senegalese fauna" lived in Sal Island since at least the Early Pleistocene (T.5, $38 \mathrm{~m}$ a.s.1.). This fauna is of interest because it spreads into the Mediterranean particularly during the Last Interglacial. The present optimum environments for this fauna in Sal Island (Morri et al., 2000) coincide precisely with those interpreted in the fossil record from the Middle and Late Pleistocene, particularly referred to as Strombus bubonius (S. latus).

Quaternary tectonic activity in the Island can be deduced from sets of joints and microfractures that affect the marine terraces deposits. The superficial distribution of morphosedimentary units suggests that a major fracture directed $\mathrm{N} 20^{\circ}-30^{\circ} \mathrm{E}$ crosses the Island favouring the deposition of marine terraces and alluvial fan deposits mainly in the upthrown fault block, and beach-barrier and lagoon systems in the downthrown fault block.

A change in vertical movement trend from uplift to subsidence or stability of Sal Island is suggested to have occurred around $330 \mathrm{Ka}$.

\section{Acknowledgements}

Research financed by Spanish Projects CGL2005-01336/ BTE and CGL2005-04655/BTE. CHM acknowledges 
financial support from the Science and Engineering Research Council of Canada and the UNESCO Chair for Global Change Study of Université du Québec à Montréal. Thanks are due to Jennifer McKay and Michel Preda (from GEOTOP) for their analytical support. This paper is a contribution to IGCP495 (Quaternary Land Ocean Interactions: Driving Mechanisms and Coastal Responses) and INQUA Commission on Coastal and Marine Processes.

\section{References}

Avila, S.P., 2000. Shallow-water marine molluscs of the Azores Archipelago: biogeographical relationships. Life and Marine Sciences 2 (A), 99-131.

Avila, S.P., Amen, R., Azevedo, J.M.N., Cachão, M., García-Talavera, F., 2002. Checklist of the Pleistocene marine molluscs of Prainha and Lagoinhas (Santa Maria Island, Açores). Açoreana 9 (4), 343-370.

Bard, E., Antonioli, F., Silenzi, S., 2002. Sea-level during the penultimate interglacial period based on a submerged stalagmite from Argentarola Cave (Italy). Earth Planetary Science Letters 196, 135-146.

Barker-Webb, P., Berthelot, S., 1836-1840. Histoire naturelle des Îles Canaries, 3 Vol.Ed. Béthune, Paris.

Callapez, P., Ferreira Soares, A., 2000. Late Quaternary warm marine mollusks from Santa Maria (Açores): paleoecologic and plaeobiogeographic considerations. Ciências da Terra (UNL) 14, 313-322.

Chen, J.H., Edwards, R.L., Wasserburg, G.J., 1986. ${ }^{238} \mathrm{U},{ }^{234} \mathrm{U}$ and ${ }^{232} \mathrm{Th}$ in seawater. Earth and Planetary Science Letters 80, 241-252.

Chen, J.H., Curran, H.A., White, B., Wasserburg, G.J., 1991. Precise chronology of the Last Interglacial period ${ }^{238} \mathrm{U},{ }^{234} \mathrm{Th}$ data from fossil coral reefs in the Bahamas. Geological Society of America Bulletin 103, 82-97.

Cuerda, J., 1989. Los tiempos cuaternarios en Baleares, Conselleria de Cultura, Educació i Esports, Govern Balear, 310 pp.

Davies, T.T., Hooper, P.R., 1963. The determination of the calcite/ aragonite ratio in mollusc shells by X-ray diffraction. Mineralogical Magazine 33, 608-612.

Delanghe, D., Bard, E., Hamelin, B., 2002. New TIMS constraints on the uranium-238 and uranium-234 in seawaters from the main ocean basins and the Mediterranean Sea. Marine Chemistry 80, 79-93.

Dumas, B., Hoang, C.T., Raffy, J., 2006. Record of MIS 5 sea-level highstads based on U/Th dated coral terraces of Haiti. Quaternary International 145-146, 106-118.

Edwards, R.L., Chen, J.H., Wasserburg, G.J., 1987. ${ }^{238} \mathrm{U}-{ }^{234} \mathrm{U}-{ }^{230} \mathrm{Th}-{ }^{232} \mathrm{Th}$ systematics and the precise measurements of time over the past 500,000 years. Earth and Planetary Science Letters 81, 175-192.

García-Talavera, F., 1987. Fauna tropical en el Neotirreniense de Santa Maria (I. Azores). Labori Societa Italiana di Malacologia 23, 439-443.

García-Talavera, F., 1999. Fauna malacológica del Cuaternario marino de Cabo Verde. Revista Academia Canaria de las Ciencias 11 (3-4), 9-25.

García-Talavera, F., Bacallado, J.J., 1981. Nuevas aportaciones a la fauna de gasterópodos marinos (Mollusca, Gastropoda) de las Islas de Cabo Verde. Boletín Instituto Español de Oceanografía 6 (328), 202-207.

Gignoux, M., 1913. Les formations marines pliocènes et quaternaires de l'Italie du sud et de la Sicile. Annales Université de Lyon 36.

Goy, J.L., Zazo, C., Bardají, T., Somoza, L., Causse, C., Hillaire-Marcel, C., 1993. Eléments d'une chronostratigraphie du Tyrrhénien des régions d'Alicante-Murcia, Sud-est de l'Espagne. Geodinamica Acta 6-2, 103-119.

Hearty, P.J., 2002. Revision of the late Pleistocene stratigraphy of Bermuda. Sedimentary Geology 153, 1-21.

Hearty, P.J., Kaufman, D.S., 2000. Whole-rock aminostratigraphy and Quaternary sea-level history of the Bahamas. Quaternary Research 54, 163-173.
Hearty, P.J., Miller, G.H., Stearns, C.E., Szabo, B.J., 1986. Aminostratigraphy of Quaternary shorelines in the Mediterranean basin. Geol. Soc. Am. Bull 97, 850-858.

Hillaire-Marcel, Cl., Gariepy, Cl., Ghaleb, B., Goy, J.L., Zazo, C., Cuerda, J., 1996. U-series measurements in Tyrrhenian deposits from Mallorca. Further evidence for two Last-Interglacial high sea-levels in the Balearic Islands. Quaternary Science Reviews 15, 53-62.

Issel, A., 1914. Lembi fossiliferi quaternari e resentí nella Sardegna meridionale. Accademia Nazionale dei Lincei, Serie 5 (23), 759-770.

Kaufman, A., Ghaleb, B., Wehmiller, J.F., Hillaire-Marcel, C., 1996. Uranium concentration and isotope ratio profiles within Mercenaria shells: Geochronological implications. Geochimica et Cosmochimica Acta 19, 3735-3746.

Lecointre, G., 1962. Le Quaternaire de l'île de Sal (archipel du Cap-Vert). Compte Rendue Sommaire des Séances Société Géologique de France, 3-92.

Lecointre, G., 1963. Sur les terrains sédimentaires de l'île de Sal, avec Remarque sur les isles de Santiago et Maio (Archipel du Cap Vert). Garcia de Orta, Serie Geologia, Lisboa II (2), 275-289.

Lecointre, G., 1965. Le Quaternaire marin de l'Afrique du nord-ouest. Quaternaria VII, 9-28.

Ludwig, K.R., Muhs, D.R., Simmons, K.R., Halley, R.B., Shinn, E.A., 1996. Sea-level records at $\sim 80 \mathrm{Ka}$ from tectonically stable platforms: Florida and Bermuda. Geology 24, 211-214.

Meco, J., Petit-Maire, N., Fontugne, M., Shimmield, G., Raoms, A.J., 1997. The Quaternary deposits in Lanzarote and Fuerteventura (eastern Canary Islands, Spain): and overview. In: Meco, J., PetitMaire, N. (Eds.), Climates of the Past. IUGS-UNESCO-Universidad de las Palmas de Gran Canaria, pp. 123-136.

Morri, C., Bianchi, C.N., 1995. Ecological niches of hermatypic corals at Ilha do Sal (Arquipélago de Cabo Verde). Boletin do Museu Municipal de Funchal, Madeira 4, 473-485.

Morri, C.R., Cattaeno-Vietti, G., Sartoni, G., Banchi, N., 2000. Shallow epibenthic communities of Ilha do Sal (Cape Verde Archipelago, eastern Atlantic). Arquipélago. Life and Marine Sciences. Ponta Delgada. Açores 2 (Suppl. A), 157-165.

Muhs, D.R., Simmons, K.R., Steinke, B., 2002. Timing and warmth of the Last Interglacial period: New U-series evidence from Hawaii and Bermuda and a new fossil compilation for North America. Quaternary Science Reviews 21, 1355-1383.

Muhs, D.R., Wehmiller, J.F., Simmons, K., York, L., 2004. Quaternary Sea-Level history of the United States. In: Gillespie, A.R., Porter, S.C., Atwater, B.F. (Eds.), The Quaternary Period in the United States. Elsevier, Amsterdam, pp. 147-183.

NOAA-WOA, 2001. 〈http://www.iridl.ldeo.columbia.edu/SOURCES/ NOAA/NODC/WOA01/>

Rolán, E., 2005. Polyplacophora and Gastropoda Part 1. In: Groh, K., Strack, H.L., Templado, J., Valdés, A. (Eds.), Malacological fauna from the Cape Verde Archipelago. Conch Books, p. 455.

Schellmann, G., Radtke, U., 2004. A revised morpho-and chronostratigraphy of the Late and Middle Pleistocene coral reef terraces on Southern Barbados (West Indies). Earth-Science Reviews 64, 157-187.

Schellmann, G., Radtke, U., Potter, E.K., Esat, T.M., McCulloch, M.T., 2004. Comparison of ESR and TIMS U/Th dating of marine isotope stage (MIS) 5e, 5c, and 5a coral from Barbados - implications for palaeo sea-level changes in the Caribbean. Quaternary International 120, 41-50.

Serralheiro, A., 1967. Sobre as praias antigas de algunas ilhas de Cabo Verde. Garcia de Orta, Serie Geologia, Lisboa 15 (1), 123-138.

Silva, L.C., Serralheiro, A., Maecdo, J.R., Gome, A., Torres, A., 1990. Carta geológica de Cabo Verde, Ilha do Sal (folhas 1 e 2), first ed. Instituto de Investigaçao Cientifica Tropical, Lisboa.

Silva, L., Torres, P., Figueiredo, M.O., Palacios, T., 1993. Fosfatização de rochas basálticas da ilha do Sal, archipélago de Cabo Verde. Garcia de Orta, Serie de Geologia, Lisboa 15 (1-2), 1-22.

Stirling, C.H., Esat, T.M., Lambeck, K., McCulloch, M.T., 1998. Timing and duration of the Last Interglacial: evidence for a restricted interval of widespread coral reef growth. Earth and Planetary Science Letters $160,745-762$. 
Stirling, C.H., Esat, T.M., Lambeck, K., McCulloch, M.T., Blake, S.G., Lee, D.C., Halliday, A.N., 2001. Science 291, 290-293.

Thompson, W.G., Spiegelman, M.W., Goldstein, S.L., Speed, R.C., 2004. An open-system model for U-series age determinations of fossils corals. Earth and Planetary Science Letters 210, 365-381.

Torres, P.C., Silva, L.C., Serralheiro, A., Tassinari, C., Munhá, J., 2002a. Enquadramento geocronológico pelo método $\mathrm{K} / \mathrm{Ar}$ das principais sequências vulcano-estratigráficas da Ilha do Sal-Cabo Verde. Garcia de Orta, Serie Geologia, Lisboa 18 (1-2), 9-13.

Torres, P.C., Silva, L.C., Serralheiro, A., Mendes, M.H., Macedo, J., Mote Gomes, A., 2002b. Geologia da Ilha do Sal. Serie de Ciencias da Terra 10. Geological Sheets I-II, 1-57.

Wehmiller, J.F., Simmons, K.R., Cheng, H., Edwards, R.L., MartinMcNaughton, J., York, L.L., Krantz, D.E., Shen, C., 2004. Uraniumseries coral ages from the US Atlantic Coastal Plain-the " $80 \mathrm{ka}$ problem” revisited. Quaternary International 120, 3-14.
Zazo, C., Goy, J.L., Hillaire-Marcel, C., Gillot, P.Y., Soler, V., González, J.A., Dabrio, C.J., Ghaleb, B., 2002. Raised marine sequences of Lanzarote and Fuerteventura revisited - a reappraisal of relative sealevel changes and vertical movements in the eastern Canary Islands during the Quaternary. Quaternary Science Reviews 21, 2019-2046.

Zazo, C., Goy, J.L., Dabrio, C.J., Bardají, T., Hillaire-Marcel, C., Ghaleb, B., González, J.A., Soler, V., 2003. Pleistocene raised marine terraces of the Spanish Mediterranean and Atlantic coasts: records of coastal uplift, sea-level highstands and climate changes. Marine Geology 194, $103-133$.

Zazo, C., Goy, J.L., Bardají, T., González, J.A., Hillaire-Marcel, C., Dabrio, C.J., Lario, J., Civis, J., Luque, L., Ghaleb, B., Borja, F., Silva, P.G., González-Hernández, F., Soler, V., Gillot, P.Y., 2004. El efecto de los ciclos climáticos en las variaciones del nivel del mar. Miscelánea en Homenaje a Emiliano Aguirre, vol. I. Geología, Museo Arqueológico Regional, Alcalá de Henares, pp. 156-167. 